2016

\title{
Minimally Democratic Administrative Law
}

Jud Mathews

Penn State Law

Follow this and additional works at: http://elibrary.law.psu.edu/fac_works

Part of the Administrative Law Commons

\section{Recommended Citation}

Jud Mathews, Minimally Democratic Administrative Law Admin. L. Rev. Forthcoming (2016).

This Article is brought to you for free and open access by the Faculty Works at Penn State Law eLibrary. It has been accepted for inclusion in Journal Articles by an authorized administrator of Penn State Law eLibrary. For more information, please contact ram6023@psu.edu. 


\title{
MINIMALLY DEMOCRATIC ADMINISTRATIVE LAW
}

\author{
Fud Matheres*
}

A persistent challenge for the American administrative state is reconciling the vast powers of unelected agencies with our commitment to government by the people. Many features of contemporary administrative law-from the right to participate in agency processes, to the reason-giving requirements on agencies, to the presidential review of rulemaking - have been justified, at least in part, as means to square the realities of agency power with our democratic commitments. At the root of any such effort there lies a theory of democracy, whether fully articulated or only implicit: some conception of what democracy is about, and what democracy requires.

While several conceptions of democracy have influenced administrative law over the years, administrative law has never come to terms with a strand of democratic thought that I term democratic minimalism. Democratic minimalists argue that conventional theories of democracy set unrealistic benchmarks to evaluate government practices, because they expect more than is reasonable of citizens, leaders, and institutions. Accordingly, minimalists seek to offer a less ambitious, more attainable account of democratic governance that nonetheless captures core normative commitments.

This Article presents the first account of minimally democratic administrative law. The Article identifies the conceptions of democracy that have dominated thinking about administrative law to this point and highlights challenges to them before outlining a competing, minimalist conception of democracy. It then revisits contemporary debates over how courts should review agency action from a minimalist standpoint.

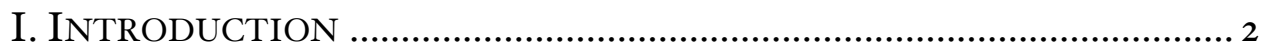

II. DEMOCRATIC THOUght AND Administrative LAW ..................... 8

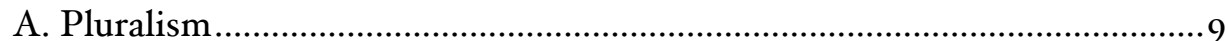

B. Civic Republicanism................................................................................ I8

C. Presidentialism ………………................................................................ 27

III. TOWARDS A Minimalist CONCEPTION OF DEMOCRACY .............32

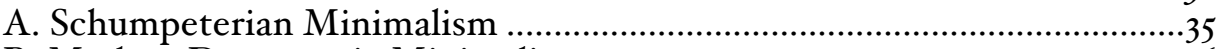

B. Modern Democratic Minimalism ............................................................ 36

IV. Minimally DEMOCRATIC Administrative LAW ...................... 39

A. Defining the Task ......................................................................................... 40

B. The Basic Framework ..............................................................................42

C. What Kinds of Reasons Must Agencies Give?..........................................50

D. Chevron Revisited ..................................................................................... 52

E. Rethinking Reviewability ....................................................................5

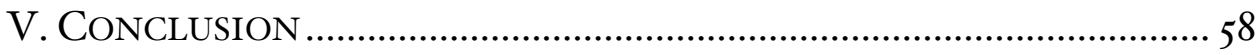

* Assistant Professor of Law, Penn State Law. Thanks are due to Robert Ahdieh, Samuel Bufford, Jamison Colburn, Lara Fowler, Christopher French, David Kaye, Kit Kinports, Adam Muchmore, Victor Romero, Stephen Ross, Sidney Shapiro, Paul Stancil, Glen Staszewski, Matthew Stephenson, Chris Walker, and Chris Zorn for useful comments on earlier versions of this paper, and to John Malchow and Kevin Schrop for research assistance. 


\section{INTRODUCTION}

The administrative state seems to have a democracy problem. On the conventional telling, the exercise of public power in a democracy is legitimate only to the extent that it can be traced back to "the people," who are ultimately sovereign. In a representative democracy, elections link officeholders to the public, and thereby legitimate their use of the coercive powers of state. It is more complicated to give an account of why unelected agency officials may legitimately exercise public power in a democracy, precisely because the electoral connection is missing. The more that agencies are making substantive policy choices with the force of law (as opposed to merely carrying out policies chosen by the legislature), the more acute the democratic problem appears. And the volume of substantive policy choices made by modern agencies in the United States is simply staggering. ${ }^{\text {I }}$

Not surprisingly, concern over the democratic legitimacy of administrative power, together with related concerns over its constitutionality, have been abiding preoccupations for scholars, officials, and reformers. In I937, President Roosevelt's Committee on Administrative Management darkly warned of the power reposed in the "headless fourth branch of government." Forty years later, James Freedman noted the "recurrent sense of crisis" that has afflicted administrative law for more than a century, with many of the concerns relating to the democratic bona fides of administrative action. ${ }^{3}$

The notion that administrative power threatens democratic governance persists. Writing for the Court a few terms ago, Chief Justice Roberts opined that "[t]he growth of the Executive Branch, which now wields vast power and touches almost every aspect of daily life, heightens the

\footnotetext{
${ }^{I}$ As one measure, the Fall 2015 Unified Agenda of Federal Regulatory and Deregulatory Actions lists 2,244 active rulemakings, of which I49 are "economically significant," meaning that they have an impact of \$roo million or more on the economy. Introduction to the Unified Agenda of Federal Regulatory and Deregulatory Actions, 80 Fed. Reg. 77709 (Dec. 15, 2015). Data from the Unified Agenda is available at Reginfo, www.reginfo.gov (last visited Jan. 28, 20I6).

2 PRESIDENT'S COMM. ON ADMIN. MANAGEMENT, REPORT WiTH SPECIAL STUDIES 37 (I937).

3 JAMES O. FREEDMAN, CRISIS AND LEGITIMACY: THE ADMINISTRATIVE PROCESS AND AMERICAN GOVERNMENT 6 (I978).
} 
concern that it may slip from the Executive's control, and thus from that of the people." 4 Still more recently, Columbia Professor Philip Hamburger argued in his 2014 book Is Administrative Power Unlareful? that "administrative law is the contemporary expression of the tendency toward absolute power- toward consolidated power outside and above the law."

Crucially, democratic concerns about administrative power are not purely academic. To the contrary, they have inspired significant changes to the administrative process and administrative law doctrine over the past half century. Judges, scholars, and policymakers have participated in major efforts to rethink and restructure how administrative power is exercised. An aim of most of these efforts has been to make the administrative state function in a matter more compatible with our democratic commitments.

This is true of the judicial innovations that opened the informal rulemaking process and judicial review to wider sets of stakeholders in the 1960 and 1970 s. $^{6}$ These developments expanded opportunities for "the people" to participate in self-government-not by voting, but by articulating their views in the agency policymaking process (or, if need be, in court). It is also true of the jurisprudence, dating from the same period, that demanded exhaustively reasoned decision making from agencies. ${ }^{7}$ A robust justification from the agency offers assurance that

${ }^{4}$ Free Enterprise Fund v. Public Company Accounting Oversight Board, $56 \mathrm{I}$ U. S. 477, 499 (2010).

5 Philip Hamburger, Is Administrative LAW UNLAWFUl? i6 (20I4). Spoiler alert: his answer is yes. For a different perspective, see Adrian Vermeule, No. Review of Is Administrative Law Unlawful? by Philip Hamburger, 93 TEX. L. REV. 1547 (2015). Justice Thomas cited Hamburger's book numerous times in his concurrence in Department of Transportation $v$. Association of American Railroads, I35 S.Ct. 1225, 1242-44 (2015) (Thomas, $\mathcal{F}$., concurring).

${ }^{6}$ See, e.g., Ass'n of Data Processing Serv. Orgs., Inc. v. Camp, 397 U.S. 150 (I970) (broadening the test for standing under the Administrative Procedure Act and thereby permitting a broader set of claimants to challenge agency action in court); Office of Commc'n of United Church of Christ v. FCC, 359 F.2d 994 (D.C. Cir. 1966) (setting aside the grant of a television license for failure to allow a public interest group intervene).

${ }^{7}$ See, e.g., Motor Vehicle Mfrs. Ass'n v. State Farm Ins., 463 U.S. 29 (1983) (applying "hard look" review to the rescission of a rule by the National Highway Traffic Safety Administration); United States v. Nova Scotia Food Prods. Corp., 568 F.2d 240 (2d Cir. 1977) (setting aside an agency decision for failure to respond adequately to an argument made by a regulated party during the notice and comment process). 
its decision was the product of careful and comprehensive deliberation about what policy choices best serve the common good. Likewise, moves to strengthen the President's role in administration, both through judicial doctrines and also through structural changes to the administrative process, have also been justified with reference to democratic values. If the President serves as the people's tribune in government, amplifying her ability to use executive branch agencies to pursue her agenda is pro-democratic.

All of these concerns, and the reforms they have inspired, rest on conceptions of democracy, whether implicit or explicit. In other words, at the root of each lies some idea of what democracy is, and what democracy requires. A conception of democracy involves both normative and positive elements: it expresses a political ideal, grounded in an understanding of how institutions of government can actually work. For instance: Some people may believe that democracy is fundamentally a matter of aggregating the preferences of individuals into policies that reflect the wishes of the majority. Others, that democracy is at heart about pursuing a shared vision of the common good, which is forged through collective deliberation. It matters how we think about democracy, because different theories of democracy underwrite different ideas about how the institutions of government should function. Indeed, some practices that are democracy-enhancing on one theory of democracy may actually have anti-democratic consequences on a different understanding of how democracy works.

A pluralist conception of democracy, which emphasizes competition among interest groups as the engine of public policy making, shaped the design of the administrative process and the development of administrative law in the decades following World War II. A number of administrative law practices also resonate with civic republican theory, which emphasizes how constructive engagement and dialogue can generate public-regarding consensus on policy matters. More recent moves towards presidential control implicitly appeal to a plebiscitary model of democracy, in which the President's actions enjoy a privileged legitimacy because the President is elected by the people as a whole. But administrative law has never had an open and sustained engagement 
with a strand of political theory that I call democratic minimalism. ${ }^{8} \mathrm{I}$ argue that it is time to do so.

Democratic minimalism is not a single theory so much as an orientation towards thinking about democracy. Minimalist theories are united by an interest in reducing the gap between theorizing and democratic practice. Minimalist theories of democracy are "minimalist" in that they set a lower bar for what it means to be democratic than most traditional theories. Minimalists characteristically argue that conventional theories of democracy are unrealistic as benchmarks to evaluate government practices, because they expect more than is reasonable of citizens, leaders, and institutions. Accordingly, minimalists seek to offer a less ambitious and more attainable account of democracy that nonetheless captures core democratic commitments. While minimalism has a historical pedigree, this way of thinking about democracy has received renewed attention from political theorists in recent years. ${ }^{9}$

One reason to engage with democratic minimalism is that there are reasons to suspect that the conceptions of democracy that have long dominated administrative law thinking may be poor guides to structuring our administrative practices. Pluralist and civic republican models of democracy have come in for forceful critiques that the standards they set for the institutions of government are unobtainable. What is more, courts' valiant but doomed efforts to hold the administrative process to these standards can lead to outcomes that are undesirable by anyone's lights. On the other hand, presidentialists may go too far the other direction, if they take the view that democracy requires nothing more than empowering an elected executive. Crucially, minimalists address the shortcomings of traditional theory not by abandoning democratic goals altogether, but instead by adjusting expectations for what government can achieve. If it does not make sense

\footnotetext{
${ }^{8}$ See, e.g., Adam Przeworski, Minimalist Conception of Democracy: A Defense, in DEMOCRACY'S VALUES 23 (Ian Shapiro \& Casiano Hacker-Cordon eds., I999). Some scholars use the phrase "minimalist conception of democracy" to denote purely procedural accounts of democracy. Procedural theories of democracy hold that any political outcomes reached through fair procedures are ipso facto democratically legitimate. See COREY BRETTSCHNEIDER, DEMOCRATIC RIGHTS: THE SUBSTANCE OF SELF-GOVERNMENT II I'I2 (2007). As I use the term, democratic minimalism does not exclude theories that impose substantive criteria for democracy (such as the principle of nondomination, discussed further below).

${ }^{9}$ See infra note 132 .
} 
to measure democratic success by the lights of traditional theory, then we require different and more realistic benchmarks for democratic success, and minimalist theories aim to provide them. ${ }^{\text {IO }}$

This Article is the first to outline a conception of minimally democratic administrative law - that is, to assess the administrative process against a minimalist conception of democracy. This vantage point of minimalism offers a fresh perspective on a set of long-running and important debates within administrative law. This Article focuses on one of the central scholarly preoccupations of administrative lawjudicial review - and evaluates existing practices from a minimalist perspective. What emerges is a new account of the role judicial review should play in administrative law that at the same time resonates with some influential contemporary arguments.

In the minimalist conception of democracy outlined below, the core task of a court reviewing agency action is to protect against domination: the abusive or arbitrary interference with persons' basic interests. Reorienting judicial review towards this end requires a redistribution of judicial scrutiny. Most of the time, courts should engage only in a lowintensity, "reasonableness" review. More judicial scrutiny is triggered by circumstances that suggest a high risk of domination: in particular, outcomes so seriously disadvantageous to affected parties that it appears the agency may have disregarded their interests entirely. Under these circumstances, the agency will face a higher burden of justification.

The minimalist conception offers new perspectives on other aspects of judicial review, including the reason-giving requirement that is a cornerstone of contemporary administrative law. Civic republicans could argue that setting very high standards for deliberation and

${ }^{\text {IO }}$ Democratic minimalism is not to be confused with other "minimalisms" that have received attention from legal scholars in recent years, notably judicial minimalism and Burkean minimalism, which is a traditionalist variant of judicial minimalism. See CASS R. SUNSTEIN, ONE CASE AT A TIME (I999); Cass R. Sunstein, Burkean Minimalism, I05 MICH. L. REV. 353 (2006). What these approaches arguably do share with democratic minimalism is a "less is more" ethos, which counsels that asking too much of institutions often leads them into error. The approach outlined here is also not to be confused with what is sometimes called "minimal rationality review" in administrative law, which amounts to rational basis review. See Ernest M. Jones, $A$ Component Approach to Minimal Rationality Review of Agency Rulemaking, 39 ADMIN. L. REV. 275 (I987). 
justification is necessary to ensure the legitimacy of agency policy choices. And as judicial review is currently practiced, as a practical matter agencies must be prepared to show that they carefully considered every alternative, and that the choice they made was superior to the alternatives. From a minimalist perspective, there is ordinarily no need for the justificatory burden on agencies to be so demanding, with the result that agencies can offer a wider class of reasons to justify their actions. Also, contemporary judicial review doctrine makes agency inaction almost unreviewable. Recognizing that agency neglect can also amount to domination, minimalism favors more symmetrical treatment of agency action and inaction. ${ }^{\text {II }}$

Democratic minimalism aligns with, and provides some theoretical ballast for, certain ideas that enjoy some currency in contemporary administrative law. Commentators have long observed the gap between what administrative law promises and what it delivers when it comes to measures aimed at enhancing the legitimacy of administrative outcomes. In particular, some scholars have argued that imposing additional justification requirements on agency decision makers can ossify the rulemaking process, with welfare-reducing results, ${ }^{\mathrm{I}}{ }^{2}$ and have advanced proposals to "de-ossify" the process, including by making judicial review less demanding. ${ }^{\mathrm{I}}$ Furthermore, some have argued that, in practice, courts do conduct judicial review at least loosely along the

${ }^{\text {II }}$ For more detail on all of these arguments, see infra Part IV.

${ }^{12}$ See, e.g., Richard J. Pierce, Jr., The Unintended Effects of Fudicial Review of Agency Rules: How Federal Courts Have Contributed to the Electricity Crisis of the I99os, 43 ADMIN. L. REV. 7 (I99I).

${ }^{13}$ See, e.g., Thomas O. McGarity, Some Thoughts on "Deossifying" the Rulemaking Process, 4I DUKE L.J. I385 (1992); Sidney Shapiro \& Richard Murphy, Eight Things Americans Can't Figure Out About Controlling Administrative Power, 6I ADMIN. L. REV. 5 (2009). For a skeptical reaction, see Mark Seidenfeld, Demystifying Deossification: Rethinking Recent Proposals to Modify Fudicial Reviere or Notice and Comment Rulemaking, 75 TEX. L. REV. 483 (1997). Works in this vein share the sense that imposing exacting requirements on agencies can make the perfect (i.e., the highest standards of participation or justification) into the enemy of the good (i.e., timely, effective regulatory responses to real problems). Sidney Shapiro taps into this idea when he advocates what he calls pragmatic administrative law. Shapiro rejects any sort of grand theory as a benchmark for administrative practices, and counsels instead "to measure the worthiness of an idea by its operation in actual experience, rather than by its consistency with the precepts of one particular theory or another." Sidney A. Shapiro, Pragmatic Administrative Law, Issues in Legal Scholarship (2005). 
lines of the proposal developed here, varying the intensity of review depending on what is at stake. ${ }^{\mathrm{I}}$

Democratic minimalism complements these lines of scholarship and onthe-ground developments in important ways. Administrative law does not lack for concrete proposals to streamline, improve, and otherwise reform the administrative process. ${ }^{15}$ But these proposals tend not to engage, at least in much depth, with debates over what makes the exercise of administrative power legitimate in a democracy. This Article offers an organizing frame for assessments of contemporary administrative practice, linking them to these broader theoretical concerns. In this way, this Article helps bring together two ongoing, largely separate conservations: one about administrative reform, and the other about political theory.

The Article is organized as follows. Part II characterizes the main strands of democratic thought that have influenced administrative law thinkers and highlights how these perspectives have influenced changes to administrative practice over the past half century. Part III then outlines the minimalist challenge to these ways of thinking about democracy, and describes an alternative democratic ideal, rooted in the concept of non-domination. Part IV assesses a number of features of judicial review from the perspective of democratic minimalism. Part V discusses some objections, and concludes.

\section{DEMOCRATIC THOUght AND ADMINISTRATIVE LAW}

This Part aims to identify the strands of democratic theory that have been most influential within administrative law over the past half century, to highlight the features of contemporary administrative law that correspond to these different ways of thinking about democracy, and to identify the principle critiques directed at each. I focus on three

\footnotetext{
${ }^{14}$ Lisa Bressman \& Glen Staszewski, fudicial Review of Agency Discretion, in A GUIDE TO JUDICIAL AND POLITICAL REVIEW OF FEDERAL AGENCIES (Michael Herz, Richard W. Murphy, \& Kathryn A. Watts eds., 2015) ("In practice, the grounds for setting aside an agency action under the arbitraryand-capricious test vary according to the nature and magnitude of that action. Thus, a court typically will apply the criteria set forth in this chapter rigorously during judicial review of high-stakes rulemaking proceedings . . . , but much more leniently when reviewing for example, an adjudicative matter that an agency would be expected to dispose of quickly.”).

${ }^{15}$ See supra note $\mathrm{I} 3$.
} 
broad families of democratic theory, which I describe as (I) pluralist, (2) civic republican, and (3) presidentialist.

It is simply not possible, in the context of this Article, to do justice to the sophistication and diversity of American democratic thought over several decades. My account necessarily relies on simplifications, not least in the way I wrangle the wide-ranging works of diverse thinkers into three discrete categories. ${ }^{\mathrm{I}}{ }^{6}$ But for present purposes, these labels suffice to illustrate the main lines of influence democratic theory has had on administrative law.

\section{A. Pluralism}

\section{Pluralist Theory}

Pluralism was the dominant theory of democracy in midcentury America, though it had had its first season of influence in the late I920s and early I930 . $^{17}$ In fact, it may understate the influence of pluralism to refer to it as a political theory at all. At a time before political theory emerged as a niche subfield separate from the broader currents of political science, pluralism was more a set of operating assumptions common to most American political scientists who studied American government (which at the time was most American political scientists). ${ }^{18}$

To understand pluralism, it helps to know what it was an argument against. For the second half of the nineteenth century, most efforts to

\footnotetext{
${ }^{16}$ In particular, deliberative democracy theorists might bristle at being forced to share the civic republican label. While theorists of deliberative democracy would be correct to insist that they deserve an entry of their own in an encyclopedia of political theory, see, e.g., ENCYCLOPEDIA OF POLITICAL THEORY (Mark Bevir ed., 20IO) (offering separate entries for deliberative democracy and civic republicanism), the similarities of their prescriptions for the administrative process warrant their treatment as a unit here. See Section II.B below.

${ }^{17}$ JOHn G. GunNell, Imagining the American Polity: Political SCIENCE AND THE DISCOURSE OF DEMOCRACY 22 (2004). Arthur Bentley introduced the pluralist conception of politics to American political science in his book The Process of Government: A Study of Social Pressures, but his ideas only became widely influential later. For a readable description of Bentley's book and its influence, see Nicholas Lemann, Conflict of Interest, THE NEW YORKER 86-92 (Aug. II, 2008). Not every prominent political science was a pluralist; E.E. Schattschneider is one notable exception. See E.E. SCHATTSCHNEIDER, The SEMisovereign PEOPle: A ReAlist's VIEW OF DEMOCRACY IN AMERICA (I960).

${ }^{18} I d$. at 4 .
} 
understand American government had been in thrall to the idea of "the state," conceived not just as a set of institutions, but as an organic "sovereign society" that preexisted government. ${ }^{19}$ Among other things, this way of thinking about government has a sharply unitarian character, in that it presupposes an already existing, unitary state that finds expression in government. ${ }^{20}$

Pluralists disagreed. The American people were an irreducibly diverse bunch, with an array of opposing interests, and efforts to bridge divisions in the service of a supervening common good were destined to fail. Americans simply did not come together as one when it came to matters of policy. Americans did, however, come together as many: they formed a multitude of groups with shared interests, or in the coinage popularized by David Truman, "interest groups." ${ }^{\text {2I }}$ Each of these groups pressed government to deliver public policies that favored its own interests. From a pluralist perspective, politics are fundamentally interest group politics, and the foremost task of government is to mediate among these competing interest group demands in forming policy. ${ }^{22}$

The pluralist vision of government-of interest group politics-is an unromantic one. Even so, most mid-century pluralists were optimistic about the capacity of democratic government to produce good outcomes. With government subject to pressure from all sides, no one interest group could consistently call the shots. So long as numerous channels for applying pressure to government actors were open to all

i9 JOHN G. GunNell, The Descent of Political Theory: The GENEALOGY OF AN AMERICAN VOCATION 29 (I993).

${ }^{20}$ The idea of the unitary state with an autonomous existence of its own was a persistent one, even as scholars sought to take a "scientific" approach to understanding government. A sentence from Columbia Professor Frank Goodnow's presidential address at the first meeting of the American Political Science Association in 1905 vividly illustrates the point. Goodnow declared that the object of political scientists should be to consider "[t]he State, as an object of scientific study, ... from the point of view of the various operations necessary to the realization of the State will." FRANK J. GOODNOW, THE WORK OF THE AMERICAN POLITICAL SCIENCE ASSOCIATION 37 (I905).

${ }^{2 I}$ DAVid BiCKNell Truman, The GOVERnMENTAL Process: POLITICAL INTERESTS AND PUBLIC OPINION 33 (IST ED. I95I).

${ }^{22}$ Arthur Bentley introduced the pluralist conception of politics to American political science in a 1908 book, but the ideas only reached their apogee of influence after the Second World War. ARTHUR BENTLEY, THE PROCESS OF GOVERNMENT: A STUDY OF SOCIAL PRESSURES (I908). 
comers, the competition to shape policy was a fair fight. And many pluralists noted favorably the numerous access points in American government, including legislative lobbying, bureaucratic engagement, and public opinion campaigns. And as Robert Dahl emphasized, updating Madison's argument from the Federalist \#io, while one interest group might hold the upper hand on one issue, no class or group in the United States was likely to dominate across the board. ${ }^{23}$

\section{In Administrative Law}

The 1960s and I970s were times of major change for the administrative process and administrative law. Many of these changes were introduced, at least in part, in an effort to bring administrative practices into better alignment with the nation's democratic commitments. And the conception of democracy that many of the legislators, judges, administrators and scholars behind these efforts subscribed to, whether implicitly or explicitly, was a pluralist one.

Administrative power is not problematic, from a democratic perspective, when agencies merely carry out instructions handed down from the people's representatives in Congress - when they act as the "transmission belt" for legislative directives, as a popular Machine Age metaphor put it. This was the standard account into the early part of the twentieth century, when - for the most part-agencies operated with limited policy discretion. ${ }^{24}$ Administration could be conceived as a technical field, wholly separate from politics. ${ }^{25}$ But by midcentury, no one could seriously maintain this view. Newer agencies were outfitted with wide-ranging discretionary powers to set policy over diverse

${ }^{23}$ ROBERT DAHL, A PREFACE TO DEMOCRACY THEORY (I956); see also ROBERT DAHL, WhO GOVERNS? DEMOCRACY AND POWER IN AN AMERICAN CITY (196I). As John Gunnell notes, although Dahl "took pains to distance himself from Madison's account [in A Preface to Democratic Theory], he developed a thesis that, in general terms, was nearly indistinguishable." GUNNELL, supra note $\mathbf{1 7}$, at 232.

${ }^{24}$ For a recent revisionist view, emphasizing the substantial powers of agencies prior to the twentieth century, see Jerry L. Mashaw, CREATING THE ADMINISTRATIVE CONSTITUTION: THE LOST ONE HUNDRED YEARS OF AMERICAN ADMINISTRATIVE LAW (2OI2).

${ }^{25}$ Woodrow Wilson took this view in an influential essay published in the late I88os, and several years later, Frank Goodnow published a book with the same starting premise. See FRANK J. GOODNOW, POLITICS AND ADMINISTRATION (I900); Woodrow Wilson, The Study of Administration, 2 POL. SCI. Q. 197 (I887). 
subjects. The question became, what made it legitimate for them to do so in a democracy?

Pluralists had a ready answer. Policymaking by agencies can be democratic so long as interest groups have access to agencies, so that they can make their cases there. And at first, many pluralists believed that they would. So for instance, Kenneth Culp Davis in the late I950s could dismiss concerns that the administrative process was biased towards certain policy outcomes, precisely because agencies were susceptible to influence from all quarters, including both interest groups and the other branches of government. ${ }^{26}$ Davis downplayed concerns over agency capture, arguing that regulatory regimes generally aim to balance public and private interests, and generally succeed in doing so. ${ }^{27}$ Writing of the Interstate Commerce Commission (ICC), Davis argues that "a finding that the ICC strikes some sort of workable balance among all of the conflicting interests affected is far from a finding of failure of the regulatory process, whatever the deficiencies of the ICC." 28

This view of the administrative process also has implications for how courts should exercise their power of review over agencies: sparingly. If agencies are permeable to interest groups already, courts have no business undoing the deals struck among stakeholders. And so, consistent with this view, Davis counseled courts to sit on their hands when possible, arguing against judicial creation of new grounds for review, and advocating internal agency review instead. ${ }^{29}$

Over time, though, it became harder and harder to maintain that kind of sunny optimism in the face of the persistent and conspicuous underperformance of agency government. By the beginning of the

${ }^{26}$ KenNeTH CUlP DAVIS, I ADMinistrative LAW TREATISE I4-23 (I958) (discussed in Reuel E. Schiller, Enlarging the Administrative Polity: Administrative Law and the Changing Definition of Pluralism, 1945-70, 53 VAND. L. REV. 1389, I408-09 (2000)).

${ }^{27}$ See Davis, supra note 26 , at 19.

${ }^{28} \mathrm{Id}$. at $2 \mathrm{O}$.

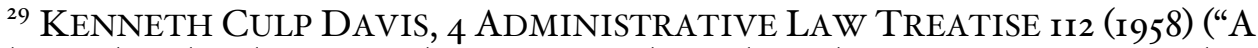
limited judicial review does not weaken the administrative process but strengthens it.") As Reuel Schiller describes, Davis' rosy view of agencies' capacity to self-regulate did not survive into the I960s, and in later works, he advocated more aggressive judicial review to keep agencies in line. See Schiller, supra note 26 , at $14 \mathrm{I} 5$. 
I960s, evidence was mounting that administrative process, left to its own devices, did not reliably incorporate the interests of relevant stakeholders to produce fair and even-handed policies. ${ }^{30}$ The mid-I950s to early i960s saw the appearance of a number of influential postmortems dissecting agency failures. ${ }^{3 \mathrm{I}}$ Most of these critical views arrived at a similar diagnosis of where the pluralist account broke down: agencies systematically favored the interests of the powerful or wellconnected over others. Instead of being open to all comers, the access points to agency influence might be closed off - an "iron triangle," Theodore Lowi would later call it, linking favored interest groups, congressional subcommittees, and agencies, to the exclusion of others. ${ }^{32}$ An imbalance of access helped to explain the curious problem of agency capture: agencies ended up serving precisely the interests of those parties they were supposed to be regulating. ${ }^{33}$

If the administrative process, left to its own devices, produces bad outcomes, it is not necessarily appropriate for reviewing courts to sit on their hands. And indeed, starting in the I960s, broad changes emerged in how judges approached judicial review over agencies. Reuel Schiller has characterized these changes as reflecting a rejection of interest group pluralism. ${ }^{34} \mathrm{I}$ argue, to the contrary, that they show courts doubling down on a pluralist conception of democracy. Courts recognize agencies' failure to even-handedly aggregate interest group preferences into policy, but they do not reject the pluralist premise that policies are properly forged out of the play of contending interest groups. I argue that many of the changes to judicial review in the I960s and I970s are best understood as efforts by courts to make the

${ }^{30}$ See Schiller, supra note 26 , at 1413.

3I MARVER H. BERNSTEIN, REgulating BusinesS By INDEPENDENT COMMISSION (1955); Samuel Huntington, The Marasmus of the ICC: The Commission, the Railroads, and the Public Interest, 6I YALE L.J. 467 (1952); JAMES LANDIS, REPORT ON REGULATORY AGENCIES TO THE PRESIDENT-ELECT (I960).

32 TheOdore J. LOW I, THE END OF Liberalism: IdEOlOgy, POliCy, AND THE CRISIS OF PUBLIC AUTHORITY (I969). The phrase "iron triangle" was originally used to describe a regional stronghold bounded by three North Korean cities during the Korean conflict. WILLIAM SAFIRE, THE RIGHT WORD IN THE RIGHT PLACE AT THE RIGHT TIME: WIT AND WISDOM FROM THE POPULAR "ON LANGUAGE" COLUMN IN THE NEW YORK TIMES MAGAZINE I70-7I (2004).

${ }^{33}$ BERNSTEIN, supra note $3 \mathrm{I}$.

${ }^{34}$ See Schiller, supra note 26 , at $139 \mathrm{I}^{-} 92$. 
administrative process more genuinely pluralist, by opening it up more fully to competing interests.

A raft of judge-initiated changes to administrative law in the I960s and I970s aimed to open the processes up more fully to those interests with a stake in the matter. ${ }^{35}$ Richard Stewart chronicled these changes in his magisterial 1975 article The Reformation of Administrative Law. ${ }^{36}$ Courts broadened access to administration in a number of ways. First, they expanded opportunities to intervene in on-the-record adjudications, the trial-type proceedings that were the prototypical form of agency action until the i970s. Notably, in Office of Communication of the United Church of Christ v. FCC, ${ }^{37}$ the D.C. Circuit Court of Appeals invalidated the grant of a television license because the agency had failed to permit a church with an interest in civil rights intervene in the licensing proceeding. According to the Court, the Federal Communications Commission (FCC) simply could not vindicate the public interest on its own: "experience demonstrates consumers are generally among the best vindicators of the public interest." The "congressional mandate of public participation" is realized not through "writing letters to the Commission" or the like, but through intervention: that is, participation in the licensing process on terms comparable to the license applicant. In other words, the Court was supervising the administrative process to bring it more in line with the interest group pluralist conception.

A series of judicial decisions also expanded public access to the judicial review of agency decisions, by lowering justiciability hurdles to the review of administrative action. Perhaps most notably, courts liberalized the legal standards for standing. In Association of Data Processing Service Organizations, Inc. v. Camp, the Supreme Court rejected the old "legal interest" test for standing to challenge agency action, opening the court doors to any party "arguably within the zone of interests to be protected or regulated by the statute or constitutional guarantee in question." ${ }^{8}$ How do we know whether a party finds within the zone of interests? Justice Douglas's answer is framed in the language of interest group pluralism. Even if statutes "do not in terms protect a

35 See also Elena Kagan, Presidential Administration, II4 HARV. L. REV. 2245, 2265-66 (200I) (characterizing these changes).

${ }^{36}$ Richard Stewart, The Reformation of Administrative Law, 88 HARV. L. REV. I667 (I975).

37 Office of Commc'n of United Church of Christ, 359 F.2d 994 (I966).

${ }^{38}$ Ass'n of Data Processing Serv. Orgs., Inc, 397 U.S. 150, 153 (1970). 
specified group," it is easy to identify "those whose interests are directly affected" by litigation under those statutes. ${ }^{39}$ Other decisions in the same period liberalized ripeness standards, bringing courts into administrative controversies earlier. ${ }^{40}$ Cheering from the sidelines, many scholars encouraged these efforts, recasting litigation as an important form of public participation in agency decision making. ${ }^{4 \mathrm{I}}$

Perhaps the most consequential change to the administrative process in the I960s and (especially) i970s was the expanded use of notice-andcomment rulemaking, whether as a matter of agency choice or congressional mandate. ${ }^{42}$ And the broader employment of notice-andcomment procedures was justified, in part, as a way to expand participation in administrative decision making. If agency adjudication resembles a judicial proceeding, rulemaking is typically more legislative in character, both in form and substance. The agency solicits comments from "interested persons" 43 and conducts public hearings before handing down a rule that is prospective in effect and "designed to implement, interpret, or prescribe law or policy." ${ }^{44}$ Informal rulemaking expanded dramatically. ${ }^{45}$ In part, this reflected choices on the part of agencies to use informal rulemaking more, choices given blessing by the courts. ${ }^{46}$

The expanded turn to informal rulemaking also reflected a deliberate design choice by Congress to vest agencies with rulemaking power as a principal policy tool. For instance, the landmark Clean Air Act of 1970 gave EPA the power and responsibility to use rules to improve air

\footnotetext{
${ }^{39} \mathrm{Id}$. at 157 .

40 Toilet Goods Assn., Inc. v. Gardner, 387 U.S. I58 (1967); Abbott Laboratories v. Gardner, 387 U. S. 136 (1967).

${ }^{4 \mathrm{I}}$ See Schiller, supra note 26, at I4I6. (describing scholarship that encouraged courts to "democratize" the administrative process by making it "genuinely participatory").

${ }_{42}^{2}$ See CROLEY, supra note $\mathrm{I}$, at $\mathrm{IO}^{-} \mathrm{O} 3$ (describing growth of rulemaking).

${ }^{43} 5$ U.S.C. $\$ 553(\mathrm{c})(2012)$.

${ }^{44} 5$ U.S.C. \$ 55I(4) (20I2). Rules may also "describ[e] the organization, procedure, or practice requirements of an agency." Id.

${ }_{45}$ CORnelius M. KERWIN \& SCOTT R. Furlong, Rulemaking: How GOVERNMENT AGENCIES WRITE LAW AND MAKE POLICY IO-I6 (20IO).

${ }^{46}$ See United States v. Florida East Coast Ry. Co., 4IO U.S. 224 (I973) (permitting an agency to dispense with the trial-type hearing required in formal rulemaking, notwithstanding statutory reference to a hearing requirement).
} 
quality. ${ }^{47}$ The Congressional choice reflected, among other things, a sense that a wide-ranging policy process, open to environmental groups as well as affected industries, would yield fair policy outcomes. The legislative history for the statute showed a conscious choice to harness public participation both in standard setting, through the notice and comment process, and in enforcement, through the statute's citizen-suit provision. In language that could have been borrowed from David Truman, the Act's chief sponsor, Edmund Muskie, justified public participation in the creation of state-level enforcement plans on the grounds that the public could thereby "bring the most effective pressure to bear for clean air." ${ }^{8}$

\section{Challenges to Pluralism}

Ultimately, however, efforts to make the administrative process more pluralist did not stem criticism of agency performance, which continued to lag. ${ }^{49}$ By the early I960s, the new field of public choice scholarship offered a persuasive social science explanation for agency failure that directly challenged the premises of pluralism. Launched by such works as Buchanan and Tullock's The Calculus of Consent ${ }^{5 \circ}$ public choice sought

${ }^{47}$ Clean Air Act Extension of 1970, Pub. L. 91-604, 84 Stat. I676, (Dec. 3I, I970).

${ }_{48}$ A Legislative History of THE Clean AiR AMENDMENTS OF i970, TOGETHER WITH A SECTION-BY-SECTION INDEX. 229, 230 (I974).

${ }^{49}$ For instance: a number of agencies that had been established with much fanfare came in for withering assessments by the end of the r95os. Reports of chronic delays and arbitrary decision-making were common, and the quality of appointments received critical attention. See, e.g., Louis J. Hector, Problems of the $C A B$ and the Independent Regulatory Commissions, 69 YALE L.J. 93I, 931-32 (I960); LANDIS, supra note 3I, at I2-I3 (I960). (In a memorable sign of the times, Landis suggested that one strategy to attract high-powered individuals to commissions would be to increase commissioners' discretionary budget for parties and social activities.) Perhaps most damningly, a series of accounts pointed to the problem of regulatory capture: that agencies were serving the interests of regulated parties, rather than the public interest. See, e.g., BERNSTEIN, supra note 3I; BERNARD SCHWARTZ, THE PROFESSOR AND THE COMMISSIONS I44-92 (I959); Huntington, supra note 3I, at 472-504. And when a number of resigning federal commissioners penned memos to President Kennedy outlining serious problems in their agencies, it drove home the point that the commissions were struggling. See LOUIS M. KOHLMEIER, JR., THE REGULATORS 82 (1969).

50 James M. BuCHANAN \& GORdon Tullock, The Calculus of CONSENT: LOGICAL FOUNDATIONS OF CONSTITUTIONAL DEMOCRACY (i962). See also MANCUR Olson, The LOGIC OF COLleCtive ACTION: PUBLIC GOODS AND THE THEORY OF GROUPS (1965). 
to apply the tools and concepts of economics to the operation of government and the production of public policy. Public choice analyses gave reasons to expect that agencies would predictably and systematically fail to translate interest group preferences into policies in an even-handed way. ${ }^{51}$ Crucially, this is so even if all interest groups in principle have equal access to the levers of regulatory policymaking, because their incentives to make use of them differ..$^{52}$ Public choice scholarship has catalogued how bureaucratic structures multiply the possible sources of regulatory dysfunction. ${ }^{53}$

Even the idea of that individual preferences could be rationally aggregated into a collective choice- a core premise of pluralist theory ${ }^{54}$ - came in for challenge during the second half of the twentieth century. ${ }^{55}$ Long ago, the Marquis de Condorcet had demonstrated that stable individual preferences over policy options can generate unstable and inconsistent collective choices, when individuals express their choices by voting..$^{56}$ In 1951, Kenneth Arrow formalized and extended

${ }^{51}$ Influential early works on the subject include: WILLIAM A. NISKANEN, BUREAUCRACY AND REPRESENTATIVE GOVERNMENT (I97I), Richard A. Posner, Theories of Economic Regulation, 5 BELL J. ECON. \& MGMT. 335 (1974); and George J. Stigler, The Theory of Economic Regulation, 2 BELL J. ECON. \& MGMT. 3 (I97I). For good overviews of the basic elements of public choice theory with an eye towards administrative law, see MASHAW, GREED, CHAOS, \& GOVERNANCE: USING PUBLIC CHOICE TO IMPROVE PUBLIC LAW IO-29 (I997); CROLEY, supra note 42, at I4-25.

${ }^{2}$ The incentives are strongest for regulated interests, which bear the costs of regulation most directly. The policies they pursue, by applying pressure either directly to agencies or to their congressional overseers, may lower social welfare as a whole, but members of the broader public will have little incentive to push for contrary policies, since the benefits to any individual are modest, the transaction costs to coordinating are high, and the possibility of free-riding on the efforts of others is a constant temptation. See JAMES Q. WILSON, THE POLITICS OF REGULATION 357-94 (I980).

${ }^{53}$ Niskanen, for instance, explores how agencies can exploit the informational asymmetries relative to Congress (that is, the agencies have more information about their domains than does Congress) to maximize their budgets at the expense of the public interest. Niskanen, supra note 97, at 77.

54 IAN SHAPIRO, THE STATE OF DEMOCRATIC THEORY 2, 3 (2003).

55 The challenge came from social choice theory, a field closely related to public choice theory. Social choice concerns the problem of collective decision making - that is, how to aggregate individual preferences over a set of policy options into a single (social) choice. See generally DANIEL A. FARBER \& ANNE JOSEPH O'CONNELL, RESEARCH HANDBOOK ON PUBliC CHOICE AND PUBLIC LAW (2010).

${ }^{56}$ For a description, see MASHAW, supra note 5I, at I2. 
the "Condorcet Paradox." Arrow's "Impossibility Theorem" demonstrates that there is no principled, fair, and consistent vote aggregation technique that can reliably translate a diverse set of preferences into a policy choice. ${ }^{57}$ Arrow's work showed that voting processes are subject to manipulation: he who sets the agenda in many cases controls the outcome. But more fundamentally, it showed that majoritarianism, which is so central to the appeal of voting, can be incoberent as a decision rule, depending on the preferences people hold over the available policy options.

Some administrative lawyers have recognized the force of the public choice critique, but none have effectively taken it on board in thinking about administrative democracy. There is a well-developed body of work on agencies in the vein of positive political theory, which analyzes institutional behavior through formalized models, and this is heavily influenced by public choice insights. ${ }^{5}$ But the name is telling: positive political theory is indifferent to normative considerations. Richard Stewart recognized the force of what amounted to the public choice critique in his celebrated 1975 article. ${ }^{59}$ But ultimately that piece despairs of satisfactorily reconciling administrative practice to our democratic values. ${ }^{60}$

\section{B. Civic Republicanism}

\section{Civic Republican Theory}

In more recent years, many influential perspectives on administrative democracy have borrowed ideas from the civic republican tradition of political thought. If some pluralists reach back to Madison as an inspiration, civic republicans can call on an even older tradition, dating back as far as Aristotle ${ }^{61}$ and influential among the Framers. ${ }^{62}$ Rather than thinking of government as a matter of aggregating the pre-formed

\footnotetext{
${ }^{57}$ For Arrow's Theorem and its proof, see NOLAN M. MCCARTY \& ADAM MEIROWITZ, POLITICAL GAME THEORY: AN INTRODUCTION 68-72 (2007). On its implications, see ERIC MASKIN \& AMARTYA SEN, THE ARROW IMPOSSIBILITY THEOREM (2OI4).

${ }^{58}$ MASHAW, supra note 5I, at IO-2I.

${ }^{59}$ See Stewart, supra note 36 , at $1683^{-85}$.

${ }^{60} \mathrm{Id}$. at $\mathrm{I} 8 \mathrm{I} 3$.

${ }^{6 r}$ MiCHAEL J. SANDEL, DEMOCRACY'S DisCONTENT: AMERICA IN SEARCH OF A PUBLIC PHILOSOPHY 26 (1996).

${ }^{62}$ For an intellectual history of modern republican thought, see J.G.A. POCOCK, THE MACHIAVELlian MOMENT: FlORENTINE POLITICAL THOUGHT AND THE ATLANTIC REPUBLICAN TRADITION (2003).
} 
preferences of individuals or groups into policies, republicans offer a grander conception of the whole political enterprise. The political space is where individuals come together to forge and pursue a shared vision of the common good. The key to the process is constructive engagement among citizens or their representatives with one another, in the form of thorough, thoughtful deliberation and dialogue. Through public-minded engagement, republicans come to better understand not only their political opponents' views, but their own as well, and to find common ground. This is a vision of politics that both promises more than pluralism, but it also requires more of citizens in the way of "civic virtues": tolerance, patience, humility, good will, and discernment.

While civic republicanism enjoys a long pedigree, its arrival on the scene as an influential position within modern political theory is fairly recent. Civic republicanism experienced newfound interest starting in the I980s and I990s. ${ }^{63}$ Political science had changed since the heyday of pluralism, and contemplating the nature of democracy was no longer on the agenda for mainstream political scientists who study American politics. ${ }^{64}$ Rather, political theory was increasingly an autonomous subfield of its own, ${ }^{65}$ and a number of theorists in the 1980 s and 1990 s advanced sophisticated arguments in favor of a civic republican conception of democracy. In the view of many adherents, civic republicanism identified a critical failure of pluralist theory: its inability to account for the polity as a political community, to which its members were bound by ties of civic obligation. In the words of Michael Sandel in his influential 1996 book Democracy's Discontents, "[t]he public philosophy by which we live cannot secure the liberty it promises, because it cannot inspire the sense of community and civic engagement that liberty requires." 66

${ }^{63}$ Quentin Skinner's The Idea of Negative Liberty, published in 1984, was in particular an important spur to the contemporary interest in civic republican ideas.

${ }_{64}^{64}$ GUNNELL, supra note 17 , at 4 .

${ }^{6} \mathrm{Id}$. at 245 .

${ }^{66}$ SANDEL, supra note 6I, at 6. Sandel identifies the reigning public philosophy of the contemporary United States as liberalism rather than pluralism. But Sandel's liberalism shares with pluralism the core ideas that individuals come to the political process with their individuals already formed and that there is no supervening public good that government should be pursuing independent of those preferences. See also GUNNELL, supra note 17 , at 242. (noting that '[b]y 
There is substantial overlap between the perspective of some civic republicans and theorists of "deliberative democracy," who began advancing their ideas around the same time, while marching under their own banner. ${ }^{67}$ Deliberative democracy theorists stress the legitimating force of the dialogic process through which individuals arrive at collective decisions. ${ }^{68}$ The arguments advanced by individual theorists differ in their particulars. In a series of influential works, philosopher Jürgen Habermas updated Kantian ethics to root the validity of norms in their capacity to meet with the agreement of all those affected following a "practical discourse" satisfying certain conditions. ${ }^{69}$ Amy Gutmann and Dennis Thompson have offered an influential perspective geared more squarely to the political, and with a particular eye to American politics. ${ }^{70}$ In their 1996 book Democracy and Disagreement, they outlined how deliberation could lead to common ground even on hotbutton topics such as abortion. ${ }^{7 \mathrm{I}}$

\section{In Administrative Law}

Some important features of the administrative process, as well as prominent perspectives for evaluating its performance, are best understood as reflecting civic republican or deliberative conceptions of democracy. The person most explicit about drawing these connections

the end of the I960s, ... pluralism and liberalism had largely become like Venus and the evening star.").

${ }^{67}$ See, e.g., JAMES S. FishKin, DEMOCRACY AND Deliberation: NeW DIRECTIONS FOR DEMOCRATIC REFORM (I99I); JOHN S. DRYZEK, Discursive Democracy: Politics, Policy, AND POlitical SCIENCE (I990); BENJAMIN BARBER, STRONG DEMOCRACY: PARTICIPATORY NORMS FOR A NeW AGE (1984); Symposium, The Republican Civic Tradition, 97 Yale L.J. I493 (1988).

${ }^{8}$ See Samantha Besson \& José Luis Martí, Introduction, in DeLIBERATIVE DEMOCRACY AND ITS DISCONTENTS xiii, $\mathrm{xv}^{-} \mathrm{xvi}$ (Samantha Besson \& José Luis Martí eds., 2006).

${ }^{69}$ JÜRGEN HABERMAS, I THE THEORY OF COMMUNICATIVE ACTION (1984); JÜRGEN HABERMAS, II THE THEORY OF COMMUNICATIVE ACTION (I987); JÜrgen HABERMAS, MORAL CONSCIOUSNESS AND COMMUNICATIVE ACTION (I99I); JÜRGEN HABERMAS , JUSTIFICATION AND APPLICATION (I993).

$7^{\circ}$ AMY GUTMANN \& DENNis F. THOMPSON, DEMOCRACY AND DisAGREEMENT (1996); AMY GUTMANN, WHY DELIBERATIVE DEMOCRACY (2004). For essays discussing Gutmann and Thompson's work, see DELIBERATIVE POLITICS: ESSAYS ON DEMOCRACY AND DISAGREEMENT (Stephen Macedo ed., I999).

${ }^{71}$ See GUTMANN \&. THOMPSON, supra note 70, at $74^{-9} 94$. 
has been Mark Seidenfeld, whose widely-read article $A$ Civic Republican Fustification for the Bureaucratic State appeared in $1992 .{ }^{72}$ Noting the rise of civic republican thinking among democratic theorists, Seidenfeld argues that legislative politics are not equal to the task of promoting constructive deliberation on the common good. "The structure and decisionmaking processes of Congress are not conducive to deliberation," Seidenfeld asserts, noting that both the intensity of electoral pressures and the outsourcing of Congress's work to committees as obstacles to authentic, broad-based deliberation. ${ }^{73}$

Instead, Seidenfeld argues, the administrative process offers the best setting for realizing the civic republican ideal. More insulated from immediate political pressures than Congress, yet more in touch with policies and the public than the judiciary, agencies "may be the only institutions capable of fulfilling the civic republican ideal of deliberative decision making." 74

The key to realizing that possibility is that agency decision-making processes must involve open deliberation, informed by participation of all relevant interests, over what policy choices serve the public interest. Seidenfeld sees in notice-and-comment rulemaking the potential for a truly deliberative process: "Comment procedures provide relatively easy access to the discourse among interest groups and the dialogue between those groups and decisionmakers." ${ }^{75}$

But this potential will not be realized if the agency has already made up its mind before the rulemaking process begins. Seidenfeld argues that courts have, and have used, techniques to ensure that the notice-andcomment process is genuinely deliberative, as opposed to mere window dressing. In his view, courts are right to require agencies to share the data on which they base their proposals and to go through notice-andcomment again when they change positions, in the interests of promoting a real engagement between agency leaders and

\footnotetext{
${ }^{72}$ Mark Seidenfeld, A Civic Republican fustification for the Bureaucratic State, I05 HARV. L. REV. I5II (I992).

${ }_{73}^{73}$ Id. at $1544,1544^{-} 46$.

${ }^{74} \mathrm{Id}$. at $\mathrm{I} 54 \mathrm{I}$.

${ }^{75} \mathrm{Id}$. at $\mathrm{1560}$; see also id. ("In particular, the paradigmatic process for agency formulation of policy - informal rulemaking - is specifically geared to advance the requirements of civic republican theory.").
} 
stakeholders. ${ }^{76} \mathrm{He}$ also argues that Congress should amend the APA to deter ex parte contacts, since private communications are at odds with the ideal of open dialogue. ${ }^{77}$ The executive branch has a role to play as well. Since the early I980s, agencies have been required to submit costbenefit analyses of proposed rules to the Office of Management and Budget (OMB) for approval. ${ }^{78}$ Seidenfeld suggests that a process for presidential review of rulemaking less squarely focused on cost-benefit analysis could require agency personnel to think more holistically about their overall missions and how individual rules serve it. ${ }^{79}$

But Seidenfeld's principal focus is on courts, and how judicial review can reinforce deliberative norms. Courts are in a unique position to promote democratic administration by insisting on the rational justifiability of agency decisions. Judicial review must test "whether the agency permitted open discourse, addressed all significant concerns reflected in the record, and generally provided a persuasive explanation of why its decision furthers the public interest." ${ }^{\circ 0}$ To this end, Seidenfeld argues that courts should require agencies to make explicit how they understand the public interest in each policy context, and why their choice best serves that interest, whenever they exercise significant discretion. ${ }^{8 \mathrm{I}}$

In many respects, on-the-ground changes in administrative law over the past several decades resonate with civic republican ideals, as Seidenfeld acknowledged. The move to promote regulatory negotiation, dating from the $198 \mathrm{os}$, aims to make policymaking more genuinely deliberative, by bringing relevant stakeholders into agencies' policy processes at an early stage. ${ }^{82}$ Also, the presidential rulemaking review process has changed along the lines that Seidenfeld proposed, at least to some degree. Executive orders from Presidents Clinton and Obama have broadened its scope outward from a pure cost-benefit analysis,

\footnotetext{
${ }^{76} \mathrm{Id}$. at $\mathrm{1} 56 \mathrm{I}$.

${ }_{78}^{77} \mathrm{Id}$. at $\mathrm{1} 559$.

${ }^{78}$ Exec. Order No. I2,29I, 3 C.F.R. \$ I27 (I98I).

${ }^{79} \mathrm{Id}$. at $155^{2-53}$.

${ }_{8}^{80}$ Seidenfeld, supra note 72 , at 1547.

${ }^{81} \mathrm{Id}$. at 1570 .

${ }_{22}$ See 5 U.S.C. $\$ \$ 56 \mathrm{I}^{-} 70$ (2012) (providing statutory authorization and procedures for regulatory negotiation).
} 
promoting a more wide-ranging exchange between the White House and agencies on the merits of particular regulatory actions. ${ }^{83}$

But probably the most important of these changes has been the adoption of "hard look" review and a stepped-up insistence on reasoned decision making more generally. The APA gives reviewing courts power to set aside agency action found to be "arbitrary, capricious, [or] an abuse of discretion." ${ }^{84}$ Historically, arbitrary and capricious review was famously deferential, ${ }^{85}$ but starting at the end of the I96os, the D.C. Circuit Court of Appeals began using arbitrary and capricious review to demand that agencies comprehensively justify their policy choices. ${ }^{86}$ As Judge Leventhal explained in a 1970 case, a court has a duty to intervene "if the court becomes aware, especially from a combination of danger signals, that the agency has not really taken a 'hard look' at the salient problems, and has not genuinely engaged in reasoned decisionmaking." ${ }^{87}$ Endorsing hard look review in 1983, the Supreme Court detailed the obligation it imposed on the agency:

Normally, an agency rule would be arbitrary and capricious if the agency has relied on factors which Congress has not intended it to consider, entirely failed to consider an important aspect of the problem, offered an explanation for its decision that runs counter to the evidence before the agency, or is so implausible that it could not be ascribed to a difference in view or the product of agency expertise. ${ }^{88}$

Although courts insisted that hard look review was not unduly intensive, in fact it frequently placed a demanding burden of justification on the defendant. ${ }^{89}$ The coin of the realm in arbitrary and capricious review had become reasoned decision-making. As the D.C. Circuit explained in Greater Boston Television Corp.,

\footnotetext{
${ }^{{ }_{3}^{3}}$ See Exec. Order No. I2866, 58 Fed. Reg. 51735 (Oct. 4, I993); Exec. Order No. 13563, 76 Fed. Reg. 382I (Jan. 2I, 20II).

${ }_{8}^{84} 5$ U.S.C. $\$(2)(A)(2012)$.

${ }_{85}$ See, e.g., National Broadcasting Co. v. United States, 319 US 190 (1943).

${ }^{86}$ See Harold Leventhal, Environmental Decisionmaking and the Role of Courts, 122

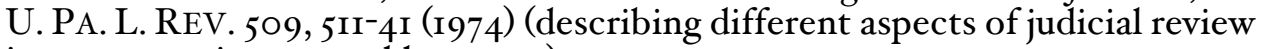
in recent environmental law cases).

${ }_{88}^{87}$ Greater Boston Television Corp. v. FCC, 444 F.2d 84I, 85I (D.C. Cir. 1970).

${ }_{88}^{8}$ Motor Vehicle Mfrs. Ass'n v. State Farm Ins. 463 U.S. 29, 43 (I983).

${ }^{89}$ See Jud Mathews, The Search for Proportionality in American Administrative Law, in THE JUDGE AND THE PROPORTIONATE USE OF DISCRETION (2015).
} 
The process [of judicial review] thus combines judicial supervision with a salutary principle of judicial restraint, an awareness that agencies and courts together constitute a 'partnership' in furtherance of the public interest, and are 'collaborative instrumentalities of justice.' The court is in a real sense part of the total administrative process, and not a hostile stranger to the office of first instance. . . Reasoned decision promotes results in the public interest by requiring the agency to focus on the values served by its decision, and hence releasing the clutch of unconscious preference and irrelevant prejudice. It furthers the broad public interest of enabling the public to repose confidence in the process as well as the judgments of its decision-makers." 90

In other words, reasoned decision making is an acceptable surrogate for the normal forms of democratic legitimation, because it trains the agency's focus on the contemplation of how its policy might best serve the public interest. ${ }^{9 \mathrm{I}}$

Much of the scholarship in a civic republican or deliberative vein focuses on the decision-making process within the agency as the site where interests and officials come together to hammer out policies in the public interest. Some scholars highlight that the back-and-forth between agency and reviewing court can be a "dialogue" with the potential to enhance the quality and legitimacy of government by agency. Seidenfeld himself noted that statutory judicial review of regulations, unlike constitutional review of legislation, can be an iterative process, in which the agency can respond to the court's critique with new justifications. ${ }^{92}$

Emily Hammond Meazell pushes the idea further, arguing that cases of "serial litigation" can amount to a court-agency dialogue, "a conversation in which the participants strive toward learning and

${ }^{90}$ Greater Boston Television Corp., 444 F.2d 84I, 851-852, (D.C. Cir. 1970). ${ }^{91}$ See also Jerry L. Mashaw, Small Things Like Reasons Are Put in a Far: Reason and Legitimacy in the Administrative State, 70 FORDHAM L. REV. I7 (200I); Glen Staszewski, Political Reasons, Deliberative Democracy, and Administrative Law, 97 IOWA L. REV. 849 (2OI2); Glen Staszewski, Reason-Giving and Accountability, 93 MINN. L. REV. I253, I286 (2009).

${ }^{92}$ See Seidenfeld, supra note 72 , at $1547^{-} 4^{8}$. 
understanding to promote more effective deliberation and outcomes." ${ }^{\prime 3}$ On Meazell's view, the exchanges between courts and agencies are legitimacy-enhancing, for reasons familiar to proponents of deliberative democracy: "when an agency clearly explains itself and how its actions relate to a previous court order [,] interested parties, Congress, and the courts can more easily understand and respond to their reasoning." ${ }^{\prime 4}$

\section{Challenges to Civic Republicanism}

Civic republicanism and deliberative democracy remain very influential perspectives within contemporary political theory. ${ }^{95}$ At the same time, they have been the subject of forceful critiques in recent years. Some have argued that the civic republican conception of democracy bears no resemblance to how government operates in modern democracies, and so is unsuitable even to serve as an aspirational model. In the past few years, empirical studies and new work in cognitive psychology have also shed light on how deliberation and reason-giving actually function in group settings, and these have cast doubt on some civic republicans' more ambitious claims.

Some critics view the deliberative processes that these models place at the core of governance unrecognizable as an account of politics, even best-case-scenario politics. Certainly, as Friedrich Schauer and others observe with reference to Gutmann and Thompson's theory, the deliberations they posit have little in common with the actual political dialogues that surround us. ${ }^{96}$ For some, the gap between our politics and the deliberative ideal is too vast for the theory even to serve as an model. ${ }^{97}$

${ }_{93}$ Emily Hammond Meazell, Deference and Dialogue in Administrative Law, III COLUM. L. REV. I722, I773 (20II). See also Christopher J. Walker, The Ordinary Remand Rule and the fudicial Toolbox for Agency Dialogue, 82 GEO. WASH. L. REV. 1553 (2014) (discussing how some courts have used remands to engage in dialogue with agencies).

${ }_{94}$ See Meazell, supra note 93 , at 1780 .

${ }^{95}$ See, e.g., Samantha Besson \& José Luis Martí, supra note 68, at xii (describing deliberative democracy as "one of the most fashionable ideas in contemporary Western political theory").

${ }^{96}$ Frederick Schauer, Talking as a Decision Procedure, in DELIBERATIVE POLITICS: ESSAYS ON DEMOCRACY AND DISAGREEMENT 22 (Stephen Macedo ed., 1999).

${ }^{97}$ Moreover, as Schauer points out, the very features of our existing political discourse that diverge from the deliberative ideal - the manifold ways in which it falls short of reasonableness-are precisely what give rise to political 
Also, in recent years, claims made by theorists about the role deliberation plays in politics have also been subjected to serious social scientific inquiry. ${ }^{98}$ Empiricists have begun taking note of deliberative theory, investigating how deliberation shapes outcomes, using qualitative case studies, natural experiments, and statistical methods. ${ }^{99}$ Dennis Thompson, one of the most important figures to advance deliberative democratic theory in the United States, characterizes the empirical evidence in support of deliberative democracy theory as "mixed or inconclusive." I00 Some of the studies even show that realworld deliberative processes tend to exacerbate, rather than reduce, power differentials between participants and lead to substantively worse decisions than non-deliberative processes. ${ }^{\text {IOI }}$

Recent work in evolutionary psychology has also challenged the presuppositions of some deliberative theorists. The so-called argumentative theory of reasoning posits that reason evolved not to search for the truth, but to persuade others. Some logical flaws in one's reasoning, such as an inability to recognize the weaknesses of one's own position, may not be aberrations, but hard-wired features of human cognition. ${ }^{\text {IO2 }}$ While it does not follow that deliberation cannot produce agreement or better outcomes, it suggests that its ability to do so depends heavily on context. Cognitive scientist Hugo Mercier has identified the failure of democratic debate in the United States as a

impasses. In a world where deliberation can work, deliberation won't have work to do: "[i]n an ideal world, people would not have the kinds of belief that deliberation would talk them out of." Id. At 24.

${ }_{98}^{8}$ See, e.g., John S. Dryzek, Theory, Evidence, and the Tasks of Deliberation, in DELIBERATION, PARTICIPATION, AND DEMOCRACY: CAN THE PEOPLE GOVERN? 237 (Shawn W. Rosenberg ed., 2007).

99 See STEPHEN ElSTUB \& PETER MCLAVERTY, DELIBERATIVE DEMOCRACY: ISSUES AND CASES (2OI4); JÜRG STEINER, THE FOUNDATIONS OF DELIBERATIVE DEMOCRACY: EMPIRICAL RESEARCH AND NORMATIVE IMPLICATIONS (2OI2).

${ }^{100}$ Dennis F. Thompson, Deliberative Democratic Theory and Empirical Political Science, II ANNU. REV. POLIT. SCI. 497, 499 (2008). Thompson argues that many of the studies are poorly formulated to test the core claims of deliberative democracy.

ior See John R. Hibilng \& Elizabeth Theiss-Morse, STEAlth DEMOCRACY: AMERICANS' BELIEFS ABOUT HOW GOVERNMENT SHOULD WORK (2OO2).

${ }^{102}$ Hugo Mercier \& Dan Sperber, Why Do Humans Reason? Arguments for an Argumentative Theory, 34 BEHAVIORAL AND BRAIN SCI. 57 (2OII); Hugo Mercier \& Hélène Landemore, Reasoning is for Arguing: Understanding the Successes and Failures of Deliberation, 33 POLIT. PSYCH. 243 (2OI2). 
function of the high-stakes, histrionic, adversarial nature of our contemporary politics. ${ }^{\mathrm{IO}}$ Taken together, the recent social scientific scholarship underlines how contingent it is for deliberation to lead to better outcomes that enjoy an enhanced sense of legitimacy. ${ }^{\text {IO4 }}$

\section{Presidentialism}

\section{Presidentialism in Theory}

Particularly if pluralism and civic republicanism seem to ask more from government than it can realistically deliver, a presidentialist conception of democracy may look like an appealing alternative. Presidentialists emphasize the privileged connection the President has to the people, as the sole governmental official who represents-and is electorally accountable to - the entire electorate. Since the I980s, presidentfocused approaches to thinking about democracy have been influential within administrative law.

Legislatures, of course, are also elected. But presidentialists tend to take a dim view of legislative politics, as a sordid business of horse-trading that really only serves the interests of the well-connected. The President, by contrast, who has a distance from the backroom dealing of the legislature, comes into office with an electoral mandate to advance the People's agenda. Presidential elections are plebiscites, in which the electorate chooses a leader based on his personal qualities and the political program that he offers. Relative to the legislature, the executive also has advantages in terms of effectiveness and responsiveness. Generally, then, it is democracy-enhancing to reduce obstacles to the President's pursuit of his agenda.

Political economists have argued that presidential government tends to produce results with majority support. ${ }^{105}$ But conceptions of democracy

${ }^{103}$ Patricia Cohen, Reason Seen More as Weapon Than Path to Truth, N.Y. TIMES, June I4, 20 II.

${ }_{104}$ See also Bächtiger et al., Deliberation in Legislatures: Antecedents and Outcomes, in Deliberation, PARTICIPATION, AND DEMOCRACY: CAN THE PEOPLE GOVERN? 82, 92-97 (Shawn W. Rosenberg ed., 2007) (identifying, through an empirical study of different legislatures, institutional and attitudinal preconditions for high-quality deliberation).

tos See, e.g., ARENDT LIJPHART, THINKING ABOUT DEMOCRACY: POWER SHARING AND MAJORITY RULE IN THEORY AND PRACTICE I5I (2008) ("My overall conclusion can be summarized in three words: presidentialism spells majoritarianism."). See also Matthew Stephenson, Optimal Political Control of the Bureaucracy, IO7 MICH. L. REV. 53 (2008) (providing a positive political theory 
that identify a single individual as the bearer of the democratic will find scant support within contemporary political theory. ${ }^{106}$ In the words of political theorist Jeff Green, "plebiscitary democracy [] is almost universally considered a profanity by democratic theorists committed to an ethical understanding of political life."107 Presidentialist conceptions of democracy typically rest, at least in part, on the plebiscitarian idea that a popular vote for a leader legitimates the actions he takes once in office. Political theorists tend to be wary of plebicitarians' valorization of executive power, and consider it a short trip from plebiscitarianism to authoritarianism. ${ }^{108}$

And in fact, the historical associations of plebiscitarianism should at least give pause to democrats attracted to presidentialism. Even the name assigned to the phenomenon of plebiscitary democracy by Max Weber-Fübrerdemokratie - could count for many as an argument against seriously entertaining the theory. ${ }^{109}$ The fact that plebiscitary democracy counted among its most enthusiastic advocates Carl Schmitt, the "crown jurist of the Third Reich," problem. But, as discussed further below, ${ }^{\mathrm{III}}$ guilt by association is not the only reason why presidentialist conceptions of democracy have found little favor among contemporary theorists.

\section{As Applied to Administrative Law}

The fact that presidentialist ideas have not been embraced by contemporary political theorists has not kept them from having an impact. To be sure, even the most aggressive proponents of executive power in American government come nowhere close to

analysis of the relationship between presidential control and majoritarianism in practice).

${ }_{106}$ There is, on the other hand, a substantial body of positive scholarship on presidential politics, which emphasizes the unique institutional characteristics of the Presidency. See, e.g., STEPHEN SKOWRONEK, THE Politics PRESIDENTS MAKE (I993).

Io7 JEFFREY E. GREEN, THE EYES OF THE PEOPLE: DEMOCRACY IN AN AGE OF SPECTATORSHIP I2O (2OIO).

${ }^{108} \mathrm{Id}$.

${ }^{109} I d$. at 142 .

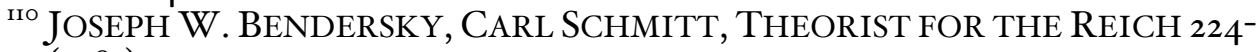
25 (1983).

${ }^{I I}$ See infra Subsection II.C.3. 
authoritarianism. ${ }^{\text {II2 }}$ Still, there were important changes to administrative law starting in the i980s that tended to amplify executive power, ${ }^{\mathrm{II}}$ and the justifications for these changes tended to echo the presidentialist conception of the President as the People's representative in government.

The revival of conservative legal theory that began in the I970s brought the concept of the unitary executive to renewed prominence by the I980s. ${ }^{\text {II } 4}$ Unitary executive arguments, which found vigorous champions within the Reagan and George W. Bush administrations, were mounted to oppose limitations on the President's control over the executive branch.

The unitary executive belonged to constitutional theory, not political theory: the claim was that an undivided executive power, with all lines of authority terminating in the President, was part of the original constitutional design. ${ }^{\mathrm{II}}$ But the constitutional arguments were often bolstered with normative claims on behalf of the desirability of a unitary and strong executive. Steven Calabresi develops some of these arguments at length in an article specifically about the normative case for the unitary executive. ${ }^{\text {II6 }}$ In Calabresi's view, a unitary executive is necessary to compensate for what he views as the manifest and unavoidable dysfunctions of legislative politics in the modern welfare state. Electoral incentives encourage wasteful spending that benefits individual districts over the commonweal, while the committee system gives members quasi-executive powers that those same electoral

${ }^{I 12}$ As Jack Goldsmith shows in his account from his time as head of the Office of Legal Counsel, there were figures in the George W. Bush administration, notably David Addington, then legal counsel to Vice President Dick Cheney, who recognized very few limits on executive power. See JACK GOLDSMITH, THE TERROR PRESIDENCY: LAW AND JUDGMENT INSIDE THE BUSH ADMinistration 78-90 (2007); see also Dana Milbank, In Cheney's Shadow, Counsel Pushes the Conservative Cause, W ASH. POST, Oct. II, 2004, at A2I.

${ }^{113}$ See infra text accompanying notes I20-I26.

II STEVen Michael Teles, The Rise OF THE Conservative Legal MOVEMENT: THE BATTLE FOR CONTROL OF THE LAW (2008); Stephen Skowronek, The Conservative Insurgency and Presidential Power: A Developmental Perspective on the Unitary Executive, I22 HARV. L. REV. 2070, 2070-103 (2009).

II See Steven G. Calabresi \& Christopher S. YoO, The Unitary EXECUTIVE: PRESIDENTIAL POWER FROM W ASHINGTON TO BUSH (2008).

${ }^{116}$ Steven G. Calabresi, Some Normative Arguments for the Unitary Executive, 48 ARK. L. REV. 23 (1995). 
incentives encourage them to misuse. ${ }^{117}$ Only a President fully in control of the Executive Branch has the capacity to confront the "congressional redistributive collective action problem." "II8 And it is pro-democratic for the President to do so, since he has the "national voice": "he, and he alone, speaks for the entire American people."'"19

Not all arguments favoring expanded presidential power are rooted in the Constitution or advanced by conservatives. Elena Kagan justified the President's aggressive use of the administrative process to advance a policy agenda in her influential article Presidential Administration, which draws particularly on the experiences of the Clinton presidency. ${ }^{\mathrm{I} O}$ Kagan strongly endorses the process for the presidential review of agency rulemaking under the auspices of the Office of Management and Budget (OMB), as initiated by President Reagan and expanded under President Clinton. ${ }^{\text {I2I }}$ She also argued in support of President Clinton's practice of issuing directives to agencies to take particular regulatory actions. ${ }^{\text {I22 }}$ Kagan's argument was not that this degree of presidential control was constitutionally compelled, but rather that it was normatively desirable, because "presidential control of administration . .. possesses advantages over any alternative control device in advancing these core democratic values." 23 Kagan's chief argument is a prospectively plebiscitarian one: a President has not only won a national election, but will face a second one, and to maintain favor with the national constituency will predictably choose policies that "reflect the preferences of the general public, rather than merely parochial interests." ${ }^{24}$

Lastly, a presidentialist conception of democracy has been used to justify the most written-about administrative law phenomenon of the last thirty-plus years: Chevron deference. In Chevron, USA Inc. v. National

\footnotetext{
${ }^{117} \mathrm{Id}$. at $34^{-} 37 ; 5 \mathrm{O}^{-} 55$.

${ }^{\mathrm{II}} \mathrm{Id}$. at 48 .

${ }^{\text {II9 }} \mathrm{Id}$.

${ }^{120}$ Kagan, supra note 35 .

${ }^{\mathrm{I21}} \mathrm{Id}$. at $2285^{-} \mathrm{90}$.

${ }^{\mathrm{I} 22}$ Kagan, supra note 35, at 2290-99.

${ }^{\mathrm{I} 23} \mathrm{Id}$. at 2326, 2332.

${ }^{\mathrm{I} 24} I d$. at 2335 . With reference to second-term presidents, Kagan has this to offer: "a President retains strong incentives to consider carefully the public's views as to all manner of issues - incentives here related to his ambition for achievement, and beyond that for a chosen successor or historical legacy." Id.
} 
Resources Defense Council, ${ }^{\mathrm{12} 5}$ the Supreme Court held that courts should defer to reasonable agency interpretations of ambiguous statutes that they administer. Writing for the Court, Justice Stevens offered this rationale:

In these cases, the Administrator's interpretation represents a reasonable accommodation of manifestly competing interests, and is entitled to deference: the regulatory scheme is technical and complex, the agency considered the matter in a detailed and reasoned fashion, and the decision involves reconciling conflicting policies. Congress intended to accommodate both interests, but did not do so itself on the level of specificity presented by these cases....

Courts must, in some cases, reconcile competing political interests, but not on the basis of the judges' personal policy preferences. In contrast, an agency to which Congress has delegated policymaking responsibilities may, within the limits of that delegation, properly rely upon the incumbent administration's views of wise policy to inform its judgments. While agencies are not directly accountable to the people, the Chief Executive is, and it is entirely appropriate for this political branch of the Government to make such policy choicesresolving the competing interests which Congress itself either inadvertently did not resolve, or intentionally left to be resolved by the agency charged with the administration of the statute in light of everyday realities. ${ }^{126}$

Cheoron was significant not least because it offered a new conception of what was at stake in statutory interpretation, one that implied new roles for legislature, court, and executive. Interpretive questions amount to policy choices, and the President should make the choice precisely because of his tight electoral connection to the American people.

\section{Challenges to Presidentialism}

The embrace of presidentialism within administrative law could be understood, in part, as a result of disillusionment with pluralist and civic republican models of democracy. Compared to these more ambitious

${ }^{125}$ Chevron, U.S.A., Inc., v. Natural Resources Defense Council, Inc. 467 U.S. 837 (1984).

${ }^{126} \mathrm{Id}$. at $865^{-66}$. 
theories, presidentialism sets its sights lower-and in this respect, it resembles minimalism. The popular election of a President surely provides at least some legitimacy for the President's acts. And the energy in the executive, ${ }^{\mathrm{I} 7}$ at least in comparison with the sclerotic legislature, opens the possibility that more executive power means more responsive government.

But if other theories promise too much, the problem with presidentialism is that it promises too little. Surely this is true of presidentialism in its strongly plebiscitary form. Such a view treats national elections, by themselves, as sufficient to legitimate the subsequent acts of the President. It follows, within this perspective, that the removal of obstacles to executive power is democracy-enhancing. A conception of democracy this thin offers no principled basis for a critique of autocratic government, so long as it features periodic elections. ${ }^{\mathrm{I} 2}$

There is a more moderate presidentialist view, that emphasizes how the electoral constraint tends to align presidential policies with majoritarian preferences. ${ }^{229}$ That may be true, but that constraint may not exhaust what we may legitimately expect from democracy. Standing for presidential elections may align the winning candidate's platform, however loosely, with the wishes of the majority, at least on some major issues. But whatever force that argument has for the first term, it loses on the first day of the second term. And even well-functioning majoritarian processes can run roughshod over minority interests. Reducing democracy to presidential elections leaves us with no conceptual tools, for instance, for articulating why the protection of minorities is relevant to democracy.

Presidentialism defines democratic commitments so far down as to very nearly throw in the towel and give up on democracy entirely. As described further below, minimalism offers a conception of democracy that is more demanding than presidentialism, but still more attainable than pluralism and civic republicanism.

\section{TOWARDS A MiNIMALIST CONCEPTION OF DEMOCRACY}

${ }_{127}$ THE FEDERALIST NO. 70 (Alexander Hamilton).

${ }^{128}$ For more on the global phenomenon of "electoral authoritarianism," see ANDREAS SCHEDLER, THE POLITICS OF UNCERTAINTY: SUSTAINING AND SUBVERTING ELECTORAL AUTHORITARIANISM (2015).

${ }^{129}$ See, e.g., LIJPHART, supra note I05, at I5I; Kagan, supra note 35, at I226. 
The previous Part outlines those stands of democratic theory that have been the most influential in the field of administrative law. The claim is not that judges or scholars have always consciously or explicitly drawn on political theory. Rather, I have argued that over the past half century, when administrative lawyers have had occasion to think about what democracy means, their answers have tended to line up with one or more of these families of theories. This alignment is not surprising, since (with the exception of presidentialism) these approaches to thinking about democracy have enjoyed broad currency among political scientists and political theorists within this period.

But importantly, these approaches to thinking about democracy have also been subject to substantial criticism. Administrative law as a field has not yet come to terms with these critiques, even when actors in the administrative law system have recognized and tried to remedy gaps between theory and reality. For instance, as discussed above, ${ }^{130}$ the "reformation" of administrative law described by Richard Stewart was a response to the perceived failure of the administrative process to deliver on the promises of democratic pluralism. But the response itself was predicated on the pluralist premise that the fundamental precondition for democratic governance is establishing a level playing field for interest group politics.

This Part outlines a minimalist conception of democracy capable of being applied to the administrative process, and built around the concept of non-domination - in essence, the idea that people should not be vulnerable in their basic interests to arbitrary or unfair exercises of power. ${ }^{\mathrm{I} I \mathrm{I}}$ This is a minimalist theory, in that it in that seeks to set a lower bar for what it means to be democratic than most traditional theories of democracy, while at the same time still capturing core democratic commitments. Others have propounded different minimalist conceptions of democracy that are not based on non-domination. ${ }^{\mathrm{I} 2}$ In

${ }^{130}$ See supra notes accompanying text 59-60.

${ }^{13 \mathrm{I}}$ The concept is developed further below; see infra text accompanying notes I48-158.

${ }^{132}$ Notably, Adam Przeworski has written about the minimum criteria electoral systems must meet to be properly considered democratic, building on scholarship from Robert Dahl. See ADAM PRZEWORSKI, DEMOCRACY AND THE LIMITS OF SELF-GOVERNMENT (2OIO); ROBERT DAHL, POLYARCHY: PARTICIPATION AND OPPOSITION I-3 (I97I); Przeworski, supra note 8. Also, Richard Posner has endorsed what he calls "pragmatic" or "Concept 2" democracy, and what I would call a form of democratic 
other words, one could reject the specific conception of democracy offered here and still accept the case for minimalism more generally. One advantage of a theory of democracy rooted in the concept of nondomination is that it is not tethered to any particular set of institutions or practices. This makes it "portable," in the sense that it can be applied in multiple contexts, including the administrative state. ${ }^{133}$

One might fault the whole project of minimalist theory for being defeatist. Is there not something deflating about settling for minimally democratic administrative law? Would we not be better off aiming for a more demanding democratic ideal, even if in practice we were likely to fall short?

There are two responses to this point. First, adopting minimalist theory may not involve settling at all. Minimalists would argue not that they offer a watered-down democratic theory, but a pure and vital one that zeroes in on the values right at the heart of our democratic impulses.

The second point is that there are reasons to believe that the theory of second best may apply. ${ }^{134}$ In certain contexts, aiming for an achievable second-best outcome leads to better results than pursuing an unobtainable first-best. ${ }^{135}$ Here, pursing of a demanding conception of democracy may lead to worse outcomes in the administrative contexts, by the lights of most observers, than aiming for a less demanding standard. A number of scholars have argued that the notice-andcomment rulemaking process, with its judicially-enforced emphasis on participation and deliberation, amounts to a kind of Kabuki theater, in which agencies put on a show for the benefit of courts. ${ }^{136}$ Agency lawyers dutifully package regulations with the justifications that they

minimalism. RiCHARD POSNER, LAW, PRAGMATISM, AND DEMOCRACY I43$57(2009)$.

${ }_{133}$ Przeworski's work, to illustrate the contrast, is specifically addressed to electoral institutions.

${ }^{134}$ See Richard G. Lipsey \& Kelvin Lancaster, The General Theory of Second Best, 24 REV. ECON. STUD. II (1956).

${ }^{135} \mathrm{Id}$.

${ }^{136}$ E. Donald Elliot, Re-Inventing Rulemaking, 4I DUKE L.J. I491, I492 (I992)

("Notice-and-comment rulemaking is to public participation as Japanese Kabuki theater is to human passions - a highly stylized process for displaying in a formal way the essence of something which in real life takes place in other venues."); see also Frank Cross, Shattering the Fragile Case for Fudicial Review of Administrative Rulemaking, 85 VA. L. REV. I243, I3I2 (I999) (making the same point). 
believe will satisfy courts, which may have little to do with the agency's real reasons for acting. ${ }^{137}$ And it is widely believed that demanding judicial review standards contribute to the ossification of the rulemaking process, generating delays and reducing agencies' functional rulemaking capacity. ${ }^{138}$ Even persons who subscribe to a richer conception of democracy may conclude that taking minimalism as a lodestar for administrative practices yields better outcomes, if it means avoiding some of these pathologies.

This Part locates the seeds for modern minimalism in the work of Joseph Schumpeter, and then outlines, in broad terms, a contemporary minimalist conception of democracy, drawing in particular on the work of political theorist Ian Shapiro.

\section{A. Schumpeterian Minimalism}

Joseph Schumpeter is widely regarded as the godfather of modern democratic minimalism. ${ }^{139}$ Though Schumpeter is best known for his work as an economist, his 1942 book Capitalism, Socialism, and Democracy contained two chapters on democratic theory that proved to be widely influential. ${ }^{40}$ Schumpeter anticipated many of the modern critiques of what he termed the "classical doctrine of democracy." Schumpeter argued that the touchstones of traditional democratic theory-the common good and the will of the people-were chimerical, and that our best efforts to aggregate individual preferences into policy are unlikely

${ }^{137}$ Importantly, longstanding administrative law doctrine instructs courts to evaluate agency actions on the basis of the agency's stated reasons, instead of "prob[ing] the mental processes" of agency decisionmakers. Morgan v. United States, 304 U.S. I, I8 (I938); see also United States v. Morgan, 313 U.S. 409, 422 (I94I) (making same point); Securities and Exchange Commission v. Chenery Corporation, 3I8 U.S. 80 (I943) (holding that agencies may not justify actions on post-hoc rationalizations).

${ }_{138}$ See supra note 13 . The debate over ossification continues; for a recent empirical study and its critique, see Jason Webb Yackee \& Susan Webb Yackee, Testing the Ossification Thesis: An Empirical Examination of Federal Regulatory Volume and Speed, 1950 - I990, GEO WASH. L. REV. 144 (2012); and Richard Pierce, Rulemaking Ossification is Real: A Response to the Testing Ossification Thesis, The George Washington University Regulatory Studies Center, March I9, 20I4, http://regulatorystudies.columbian.gwu.edu/ rulemakingossification-real- response-testing-ossification-thesis.

I39 JOHN MEDEARIS, JOSEPH SCHUMPETER'S TwO THEORIES OF DEMOCRACY I-4 (2OOI).

I40 JOSEPH A. SCHumpeter, CAPITAlism, SOCIALISM AND DEMOCRACY $250-83(2013)$. 
to yield "what people really want." ${ }^{14 \mathrm{I}} \mathrm{He}$ argued that citizens generally failed to take a sober and serious interest in the finer points of national political issues - and that it would be unreasonable to expect them to. ${ }^{1{ }^{2}}$ Schumpeter hammered political scientists of his day for offering panglossian theories of democracy that had nothing in common with political realities. ${ }^{\text {I43 }}$

In contrast, Schumpeter offers a very different, and decidedly unromantic, understanding of what democracy at root is about. For Schumpeter, "the democratic method is that institutional arrangement for arriving at political decisions in which individuals acquire the power to decide by means of a competitive struggle for the people's vote." 44 Entirely absent in this conception is any suggestion that "the people" are meaningfully engaged in a project of self-rule. The nearest thing democracy can offer in this direction is the disciplining force of a market - the market for votes - that incentivizes leaders to align policy choices with public preferences, at least broadly. The ever-present possibility of being voted out of office provides insurance against abusive or autocratic rule. A functioning democracy also necessarily provides a nimbus of freedoms that are preconditions for the competitive struggle for votes that Schumpeter describes. ${ }^{\mathrm{I} 45}$

\section{B. Modern Democratic Minimalism}

Schumpeter's theory of democracy had an "extraordinary impact," influencing a diverse set of scholars, ${ }^{146}$ including several contemporary theorists. Schumpeter's work is often regarded as conservative, whether owing to his low regard for the capacity of the average voter or from association with his staunchly capitalist economic theories. But

\footnotetext{
${ }^{\mathrm{I} 4 \mathrm{I}} \mathrm{Id}$. At 250-52; 254 .

${ }^{142}$ "Normally, the great political questions take their place in the psychic economy of the typical citizen with those leisure-hour interests that have not attained the rank of hobbies, and with the subjects of irresponsible conversation. These things seem so far off; they are not at all like a business proposition; dangers may not materialize at all and if they should they may not prove so very serious; one feels oneself to be moving in a fictitious world." Id. at $26 \mathrm{I}$.

${ }^{\mathrm{I} 43}$ SCHUMPETER, supra note I4O.

${ }^{144} I d$. at 269.

${ }^{145}$ SCHUMPETER, supra note I4O, at 272.

${ }^{146}$ ROBERT LORING ALLEN, OPENING DOORS: THE LIFE AND WORK OF JOSEPH SCHUMPETER I33 VOL. 2 (I99I); see also Medearis, supra 139 note, at $\mathrm{I}^{-}$ 2.
} 
importantly, contemporary work shows that there is nothing inherently conservative about democratic minimalism. ${ }^{\mathrm{I}}{ }^{4}$

In addition to political scientists working with minimalist conceptions of democracy, there are a number contemporary political theorists who posits non-domination as a core political ideal. Ian Shapiro in particular has made the argument, in detail and at length, that non-domination is a democratic ideal, because it speaks to the most basic concerns of democratic theory. As mentioned above, a minimalist theory of democracy based on the concept of non-domination, as opposed to around specific electoral processes or institutions, recommends itself to the present project because it can be fairly readily applied to the administrative context. ${ }^{\mathrm{I} 8}$ But it is by no means the only minimalist approach to democracy.

For Schumpeter, the touchstone of democracy is competitive elections. But in what way exactly do competitive elections serve a democratic ideal, if voting does not unproblematically aggregate individual preferences or else express some general will? Shapiro offers an answer: Competitive elections prevent any one group from monopolizing power over the long term, and thereby dominating others. It is difficult to define exactly what collective self-rule entails, but far easier to identify what negates it: domination by others. And so for Shapiro, democracy is ultimately "a means of managing power relations so as to minimize domination." "149

The problem of domination has received sustained attention from political theorists in recent decades. ${ }^{150}$ The concept of domination figures importantly in the work of Jürgen Habermas, Michel Foucault, Michael Walzer, Quintin Skinner, and Phillip Petit, among others. ${ }^{15 \mathrm{I}}$ Theorists commonly understand domination to be a particular kind of

${ }^{147}$ SHAPIRO, supra note 54 , at 55.

${ }^{148}$ See supra text accompanying notes $13^{2}-\mathrm{I} 33$.

${ }^{149}$ SHAPIRO, supra note 54 , at 3.

${ }^{150}$ Domination has also figured in scholarship on administrative law by Evan Criddle. See Evan Criddle, When Delegation Begets Domination: Due Process of Administrative Lawmaking, 46 GA. L. REV. II7 (20II). As the title to Criddle's article suggests, and in contrast with the present approach, see infra Part IV, he views due process protections as the key to preventing administrative domination.

${ }^{151}$ See David Dyzenhaus, Response to Ian Shapiro's On Non-Domination, 62 U. TORONTO L.J. 337 (20I2); Ian Shapiro, On Non-Domination, 62 U. TORONTO L.J. 306-32(2012). 
unfreedom that results from abuses of power. ${ }^{152}$ In one formulation, domination is "subjection to the whims or arbitrary will of another." 53 In the formulation favored by Shapiro, domination involves having one's basic interests systematically disregarded in contexts where they should matter. Basic interests are the most fundamental ones: persons have basic interests "in the security, nutrition, health, and education needed to develop into, and live as, normal adults," and in "developing the capacities needed to function effectively in the prevailing economic, technological, and institutional system, governed as a democracy over the course of their lives." ${ }^{254}$

If older democrats did not use the language of domination, it was nonetheless of concern to them. Madison famously argued for an extended republic in Federalist Io precisely because in a large and diverse society, there is no "majority faction" with homogeneous interests that could run the table on politics, getting its way on every issue. ${ }^{155}$ In other words, the extended republic is a device to protect against domination.

Because domination is a function of the power dynamics rather than the formalities of relationships, identifying it in practice always requires context-specific judgments. Shapiro writes that hierarchies, for instance, merit scrutiny for their potential to "atrophy into illicit systems of domination," ${ }^{, 56}$ but they are not necessarily illegitimate: "There is a world of difference, for instance, between a teacher's requiring a student to do her homework and his taking advantage of his powerful position to engage in sexual harassment of her. The latter is domination, but the former is not." ${ }^{57}$ Ultimately, the aim of democratic government is "to enable people, as much as possible, to pursue the activities that give life its meaning and purpose while limiting the potential for domination that accompanies those activities." 158

If non-domination is the touchstone of democratic legitimacy, Shapiro offers a number of off-the-shelf institutional strategies that can be

\footnotetext{
${ }^{152}$ Shapiro, supra note I5I, at 293.

${ }^{153}$ Dyzenhaus, supra note I5I, at 340. Dyzenhaus here is characterizing the views of Phillip Pettit.

${ }^{154}$ Shapiro, supra note 15I, at 294.

${ }^{155}$ THE FEDERALIST NO. Io (James Madison).

${ }^{156}$ Shapiro, supra note $15 \mathrm{I}$, at 338.

${ }^{157}$ SHAPIRO, supra note 54, at 4.

${ }^{158}$ Shapiro, supra note I5I, at 338 .
} 
employed in different settings to bring decision-processes more in line with democratic norms. Perhaps the most basic is the principle of affected interests: "everyone affected by the operation of a particular domain of civil society should be presumed to have a say in its governance."159 Context is key: what is essential is that the basic interests of persons are taken into account when decisions affect them, whatever the mechanism. Importantly, for Shapiro the right to have a stake in decision making is not premised on anything so grandiose as a belief that deliberation will produce consensus among stakeholders. Rather, it serves as a warrant against domination. Having one's views taken into consideration in a decision-making process is incompatible with true domination.

It bears emphasis that Shapiro presents non-domination as a democratic ideal, as opposed to, for instance, just an ideal of justice. Nondomination, on this view, is something like the lowest common denominator of democratic theory, a value immanent in all reasonable conceptions of democracy. This minimalist approach to democracy recommends itself to the extent that the ambitions of conventional theories of democracy - to arrive at a common good or collective will by aggregating individual preferences or deliberating - are unattainable. ${ }^{160}$ This conception of democracy is minimalist but not proceduralist, in that the principle of non-denomination provides a substantive yardstick to evaluate whether outcomes are truly democratic.

This conception of democracy, like most political theory constructs, is pitched at a high level of generality. By itself, the theory has limited resolving power, as its key operative terms are fairly open-ended. Deciding actual cases will require making choices, including choices about what counts as basic interests and domination. The next Part illustrates one set of possibilities for how this approach to thinking about democracy could inform how courts carry out judicial review.

\section{Minimally Democratic Administrative Law}

\footnotetext{
${ }^{159}$ IAN SHAPIRO, DEMOCRATIC JUSTICE 37 (I999).

Arguing that proponents of aggregation and deliberation alike "overestimate the importance of the idea of the common good for democracy," Shapiro offers a "stripped-down" view of the common good, as "that which those with an interest in avoiding domination share." Shapiro, supra note 54, at 3 .
} 


\section{A. Defining the Task}

The aim of this Part is to consider democratic minimalism as a normative yardstick for administrative law, and specifically, for the judicial review of agencies by courts. ${ }^{161}$ This Part does not offer a wholesale reimagining of the field of administrative law from the minimalist perspective, which is well beyond the scope of a single law review article. The focus here is deliberately restricted to the judicial review of agency actions, and further, to a few key topics within judicial review.

The arguments made in this Part are best understood as answers to the question: from the perspective of democratic minimalism, how can judicial review best enhance the democratic legitimacy of agency action? There are two points that need to be made at the outset about this way of framing the question.

First, the democratic mode of legitimation is not the only one available for uses of public power. For instance, judicial decisions are generally considered legitimate not because judges are elected ${ }^{162}$ but because of the impartiality of judges and the procedural fairness of trials. ${ }^{163}$ In administrative law, agency adjudication is structured as a quasi-judicial proceeding, with APA provisions guaranteeing an impartial decision maker $^{164}$ and procedural fairness. ${ }^{165}$ In highly technical contexts, subject

16r This Part represents my own application of the minimalist conception of democracy elaborated in the previous Part: I am not attempting here to channel or speak for any of the theorists of non-domination mentioned in that Part. Ian Shapiro has written about what his theory implies for judicial review, but not in the administrative law context. See SHAPIRO, supra note 54, at 6477.

${ }^{62}$ David Pozen does explore the idea that state judicial elections are a manifestation of popular constitutionalism in a 2010 article. David E. Pozen, Fudicial Elections as Popular Constitutionalism, II COLUM. L. REV. 2047 (2010).

${ }_{163}$ On the traditional understanding, the judicial process did not need to be democratic because it does not involve making law, but applying law. Even admitting that a sharp distinction between making and applying law cannot be maintained, it is still possible to argue, as the legal process scholars did, that judicial lawmaking is different from legislating, and is legitimate so long as courts play their proper role of resolving disputes through the judicial method. See William N. Eskridge Jr \& Philip P. Frickey, The Making of the Legal Process, IO7 HARV. L. REV. 203I (I993).

${ }^{164}$ Administrative Procedure Act, 5 U.S.C. $\$ 556(\mathrm{~b})(2012)$.

${ }^{165}$ Administrative Procedure Act, 5 U.S.C. $\$ 554(\mathrm{~d})$ (2012) (barring ex parte contacts with the agency adjudicator and separating investigatory and prosecutorial functions). 
specific expertise may properly play a legitimating role in agency decision making. ${ }^{\text {I66 }}$

It is in areas where agencies make significant policy choices-where they are performing a role similar to the legislature's - that the need for democratic legitimation is highest. Agencies typically make these choices in the context of rulemakings, and accordingly, the discussion below focuses mostly on judicial review of rulemaking. ${ }^{167}$ But of course, even in the context of agency policy choices, judicial review does not only exist to ensure that administrative actions are democratically legitimate. most important rationale judicial review exists for the sole purpose of. Judicial review serves a number of other ends as well, such as vindicating individual legal entitlements, and Congress has often crafted agency-specific judicial review provisions for context-specific reasons. ${ }^{\text {I68 }}$ While the discussion below focuses to judicial review's capacity to reduce domination, in a bigger picture perspective, this is one function to be balanced against others.

Second, to ask how judges can enhance the democratic legitimacy of the administrative process arguably treats courts as standing outside of the system of government and the pull of politics altogether. It is standard operating procedure for legal scholarship to instruct courts in how they should do their work, but doing so implicitly extends to judges more benefit of the doubt than other officials typically receive. A prescription aimed at courts will only be effective to the extent that judges perform

${ }^{166}$ Expertise was perhaps the leading rationale for delegations to agencies during the first two generations of the modern administrative state. See, e.g., JAMES M. LANDIS, THE ADMINISTRATIVE PROCESS 22-28 (I938).

${ }_{167}$ Because agencies are permitted to make policy also through adjudications, see SEC v. Chenery Corp., 332 U.S. 194, 202-03 (1947), the focus is not exclusively on review of rulemakings.

I also focus here on substantive review by courts, as provided for in 5 U.S.C. $\$$ 706(2)(A) (2012). Courts' construction of the rulemaking requirements of 5 U.S.C. $\$ 553$ (20I2) also have been shaped by an effort to make the rulemaking process more deliberative and participatory, for instance, by requiring agencies to make relevant documents available to interested parties, see Portland Cement Ass'n v. Ruckelshaus, 486 F.2d 375 (D.C. Cir. 1973), and to respond to significant comments, see Reytblatt v. U.S. Nuclear Regulatory Comm'n, I05 F.3d 715 (D.C. Cir. 1997). A minimalist conception of democracy has implications for these practices as well, but the focus here is on the conduct of substantive judicial review.

${ }^{168}$ See, e.g., Melissa F. Wasserman, Deference Asymmetries: Distortions in the Evolution of Regulatory Law, 93 TEX. L. REV. 625 (2015) (discussing different judicial review arrangements for patent grants and patent denials). 
in good faith, unswayed by strategic or political considerations of their own. But the idea that courts can be trusted is more often assumed than argued for.

This is a fair criticism to level at most work that looks to courts to ameliorate the political dysfunctions of other institutions, including this piece. But while accepting the criticism, I argue that applies here in slightly attenuated form. Precisely because minimalism prescribes a baseline norm of low-intensity review (as described further below), it expects less of courts, and leaves less scope for judicial self-dealing, than theories that authorize courts to engage in more searching, wideranging review. ${ }^{169}$

\section{B. The Basic Framework}

I argue from the premises of democratic minimalism for a general framework for judicial review that combines a baseline norm of lowintensity, reasonableness review with the possibility of elevated scrutiny when agency actions threaten serious harms to persons' basic interests. First, I lay out the basics of the framework, and then I apply it to some specific aspects of judicial review, making reference to previous cases to illustrate my points.

\section{A Return to Reasonableness}

The pluralist and civic republican conceptions of democracy call for vigorous judicial review. This is so because they set a high bar for what counts as democratically legitimate administrative actions. Agencies' processes must be solicitous of all of the groups with an interest in the action in question, and on equal terms. Agencies must give a hard look to all of the arguments proffered by the various stakeholders, and explain in detail why the chosen course of action is justified in light of them. Reviewing courts, in turn, must apply ample scrutiny to the agency's action to verify that the agency has cleared the bar.

From a minimalist perspective, the pluralist and civic republican conceptions of democracy demand more than is realistic from agencies. Accordingly, agencies will consistently fail to clear the bar the bar that they set, which means that reviewing courts applying these standards

${ }^{169}$ One issue that is not a particular problem for democratic minimalism is the concern that decision-making by unelected judges is inherently antidemocratic, since, on this view of democracy, the touchstone of legitimacy is the protection of people's basic interests, rather than electoral accountability. 
will constantly be setting aside agency action. But there is no reason to suppose that frequent judicial invalidations will systematically make agency outcomes more meaningfully democratic. The predictable consequence of having courts require agencies to meet unrealistic standards of inclusion and rationality is, instead, the ossification of agency processes.

As a general matter, then, minimalism counsels in favor of restraint when it comes to the judicial review of agencies. A reviewing court is not looking for a perfect weighing of the different interests at stake, or a comprehensively rational justification of the agency's action. Instead, a court is looking to see that no one is being systematically disregarded or arbitrarily harmed in decisions that adversely affect his or her basic interests. Below, I discuss what should trigger additional scrutiny, and what form that scrutiny should take. The default position, however, should be a basic reasonableness review.

As Justice Frankfurter put it, judicial standards of review can really only express a mood, ${ }^{\mathrm{I}>}$ and "reasonableness" can convey varying degrees of laxity ${ }^{171}$ At the limit, reasonableness review can entail hardly any review at all, as in the British Wednesbury standard, ${ }^{\mathrm{T} 2}$ which will only flunk an agency decision "so outrageous in its defiance of logic or accepted moral standards that no sensible person who had applied his mind to the question to be decided could have arrived at it."173 "Rational basis with bite" is nearer the mark: more intensive than Wednesbury, but less intensive than full hard look. ${ }^{174}$ I discuss further what kinds of agency justifications survive reasonableness review below. ${ }^{175}$

2. Varying the Intensity of Review

${ }^{170}$ Universal Camera Corp. v. Labor Board, 340 U.S. 474, 487 (I95I).

${ }^{171}$ For a discussion of some of the different possibilities, see Giancinto della Cananea, Reasonableness in Administrative Law, in REASONABLENESS AND LAW 295 (Giorgio Bongiovanni, Giovanni Sartor \& Chiara Valentini eds., 2009).

${ }_{172}$ Associated Provincial Picture Houses v. Wednesbury Corp. [I948] I KB 223.

${ }^{173}$ Council of Civ. Serv. Unions v. Minister for the Civ. Serv. [1985] AC 374, $4 \mathrm{IO}$.

${ }_{174}$ See Scott A. Keller, Depoliticizing fudicial Review of Agency Rulemaking, 84 WASH. L. REV. 4I9, 470-7I (2009). Keller describes the majority's approach in FCC v. Fox Television Stations, Inc., 556 U.S. 502 (2009), as an example of "rational basis with bite" review.

${ }^{175}$ See infra Part IV.D. 
It has been argued that the existing standards of judicial review already amount to a single reasonableness requirement. ${ }^{176}$ In fact, though, the evidence suggests that there is substantial variability in how intensively review is carried out in practice. Significantly, doctrine seems to provide less guidance as to how the intensity of review varies than one might hope: courts do not agree, for instance, on whether substantial evidence review is more stringent than, less stringent than, or equivalent in stringency to arbitrary and capricious review. ${ }^{177}$ At the same time, there appear to be variations in the intensity of review actually applied by courts that are wholly unconnected to doctrine. For instance, certain agencies appear to routinely receive more deference from courts than others. ${ }^{178}$ There are some areas of doctrine that address how the intensity of review varies: for instance, with respect to agency statutory interpretations, Cheoron review is more deferential than Skidmore review, ${ }^{179}$ and the intensity of Skidmore review varies depending on features of the agency's interpretation. But these are the exception rather than the rule: for the most part, the law is unclear on how the intensity of review should vary across contexts.

Minimalism offers a useful guiding principle with respect to the basic question of how the intensity of judicial review should vary. If democracy at root is about non-domination, then judicial review is democracy-enhancing when it is deployed to detect and correct situations where parties' basic interests are unjustifiably disregarded with results that cause them serious harm. Reasonableness review is appropriate as a baseline norm, but harms to the basic interests of affected parties can trigger a higher duty of justification.

To be more specific, courts should depart from the norm of relaxed review when a party plausibly claims that an agency inappropriately disregarded its legitimate interests, or otherwise acted so arbitrarily as to constitute an abuse of power, resulting in serious harm to the party. Under these circumstances, hard look review and associated doctrinesthe requirement that agencies respond to all significant comments; ${ }^{180}$ the requirement that agencies make available the data that support their

${ }^{176}$ See David Zaring, Reasonable Agencies, 96 VA. L. REV. 2317 (2010).

${ }_{177}$ Different courts have given all three answers. See Mathews, supra note 89.

${ }^{178}$ See Kathryn Kovacs, Superstatute Theory and Administrative Common Law, 90 INDIANA L.J. I2O7 (2015).

${ }^{179}$ Skidmore v. Swift \& Co., 323 U.S. 134 (1944).

${ }^{180}$ United States v. Nova Scotia Food Prods. Corp., 568 F.2d 240 (2d Cir. 1977). 
action $^{\text {I8I }}$ - should apply with full effect. The court should ask: Did the agency give an adequate, contemporaneous response to the arguments made by the claimant? Has the agency demonstrated that it considered alternatives that are less burdensome to the adversely affected? Has it given adequate reasons for choosing the policy it selected over those alternatives? Ordinarily, the focus of the inquiry should be on whether the agency adequately took into account the interests of those affected by its decision. But an agency's disregard of other relevant, important factors and other blatant errors could also be grounds for setting aside its decision, since truly arbitrary uses of power that cause potent harms can also amount to domination. ${ }^{182}$

This framework for review is broadly similar in spirit to proposals some scholars have made to peg the intensity of review to the openness of the agency's process to interest group input. ${ }^{183}$ It also resonates with doctrines governing intensity of review in some other administrative law systems. For instance, a general principle of European Union Law is proportionality: the benefits from measures must justify the burdens

\footnotetext{
${ }^{181}$ Portland Cement Ass'n v. Ruckelshaus, 486 F.2d 375 (D.C. Cir. I973).

${ }^{182}$ See supra text accompanying note 153 . Statutes typically specify the factors that agencies should consider in making policy choices, and in some cases, statutes bar agencies from taking into account important interests of affected groups. For instance, under the Clean Air Act, EPA is instructed to set National Ambient Air Quality Standards (NAAQS) at the level "requisite to protect public health" and "public welfare", without reference to compliance costs. See 42 U.S.C. \$7409(b)(I)-(2) (2012); Whitman v. Am. Trucking Ass'ns, Inc., 53I U.S. 457 (200I). Although lower levels will predictably result in more job losses, Congress has made a choice that the agency should make its choice on the basis of health considerations, to the exclusion of economic considerations. In circumstances such as this, the impact of the agency's action on the economic interests of those affected may trigger heightened scrutiny, but the agency defends its action by showing that it adequately considered a different set of factors.

${ }_{183}$ See Wendy E. Wagner, Administrative Law, Filter Failure, and Information Capture, 59 DUKE L.J. I32I (2OIO); David Fontana, Reforming the Administrative Procedure Act: Democracy Index Rulemaking, 74 FORDHAM L. REV. 8I (2005). A difference between these proposals and the one presented in this Article is that the former are more focused on process, or inputs-was the agency's rulemaking sufficiently participatory?-and the latter is oriented more towards substance, or outputs. While opportunities for interested parties to participate in agency policy-making processes, for instance, by commenting on rulemaking proceedings, are appropriate, what is critical, from the minimalist perspective outlined here, is that the agency gives appropriate weight to the relevant interests.
} 
they impose on adversely affected parties. ${ }^{184}$ Proportionality review can be conducted with greater or lesser deference to the judgments of policymakers. And proportionality applies less deferentially the more that especially important interests - those protected by rights - are implicated. ${ }^{185}$ In other words, the more a decision affects basic interests, the more intensively the court will scrutinize the government's justification for it.

To make matters more concrete, I offer four cases help to demonstrate how the framework could apply, and to illustrate where it would both overlap with and differ from current practices. The analysis in all cases reflects a series of contestable judgments: about what kind of harms should trigger heightened scrutiny; about what different levels of scrutiny mean in practice; and to what extent the decisions under consideration aligned with the framework considered here. For these reasons, the discussion shows what minimally democratic judicial review could look like in practice, rather than what it must look like.

Two cases (FCC v. Fox Television Stations, Inc. ${ }^{186}$ and Motor Vebicles Manufacturers Association v. State Farm Insurance ${ }^{187}$ ) are offered to show, respectively, how courts should and should not review run-of-the-mill agency policy choices. The other two cases (Fudulang v. Holder ${ }^{188}$ and Industrial Union Dep't, ALF-CIO v. Hodgson ${ }^{\mathrm{I} 89}$ ) are offered to show, respectively, how courts should and should not conduct review when agency action threatens serious harm to parties' basic interests.

Fox Television Stations concerned a challenge to a change in FCC policy regarding the broadcast of "fleeting expletives": non-repetitive, nonliteral uses of vulgar language. After fielding numerous complaints following a series of live award show broadcasts in which celebrities indulged in salty language, ${ }^{190}$ the agency eliminated a safe harbor that

${ }^{184}$ See TAKis Tridimas, The General Principles of EU LaW I36-23I (2006).

${ }^{185}$ See Paul Craig, Gráinne de Búrca, EU Law: TeXt, Cases, And MATERIALS 544-5I (2OII); Julian Rivers, Proportionality and Variable Intensity of Review, 65 CAMBRIDGE L.J. I74 (2006).

${ }^{186}$ Fed. Commc'n, et al. v. Fox Television Stations, Inc., 556 U.S. 502 (2009).

${ }^{187}$ Motor Vehicle Mfrs. Ass'n of U.S., Inc. v. State Farm Mut. Auto. Ins. Co., 463 U.S. 29 (1983).

I88 Judulang v. Holder, I32 S.Ct. 476 (2OII).

${ }^{189}$ Industrial Union Dept., AFL-CIO v. Hodgson, 499 F.2d 467 (D.C. Cir. I974).

${ }^{190}$ See Fox Television Stations, 556 U.S. at 508-ıо (describing the incidents). 
had previously shielded fleeting expletives from liability under the indecency standards. ${ }^{19 \mathrm{I}}$ Broadcasters challenged the action as arbitrary and capricious and won below, but lost before the Supreme Court. Writing for the Court, Justice Scalia rejected the suggestion that the reasons for the agency's new approach to fleeting expletives needed to be better than the reasons for its past policy: "it suffices that the new policy is permissible under the statute, that there are good reasons for it, and that the agency believes it to be better, which the conscious change of course adequately indicates." ${ }^{192}$ The reasons the agency gave for expanding the scope of enforcement - that literal and nonliteral uses of offensive words were equally indecent; that isolated utterances could be harmful to children and lead to more uses of offensive languagewere "entirely rational."193 The Court's majority also disagreed with the dissenting justices' conclusion that the agency was insufficiently attentive to the First Amendment implications of its policy. ${ }^{194}$

The Supreme Court applied only moderate scrutiny to the FCC's order. The Court required reasons for the agency's action, but not a demonstration that this action was better than the alternatives. Nor did the Court require as exacting an analysis of the order's collateral impacts as the dissent would have demanded. From the perspective of democratic minimalism, nothing more was required to ensure that the agency's action was legitimate. The interests at stake were important; in litigation, they almost always are. ${ }^{195}$ But the FCC's action did not pose a serious threat to anyone's basic interests. ${ }^{196}$ Insofar as judicial review in a democratic state should be aimed at protecting persons against domination by agency power, the kind of reasonableness review that the majority provided was sufficient.

In State Farm, the Supreme Court reviewed a decision by the National Highway Traffic Safety Administration (NHTSA) to rescind a passive restraint requirement for new cars. The agency had explained that, contrary to its initial projections, most auto manufacturers would meet the requirement through the use of detachable automatic seatbelts, and

\footnotetext{
${ }^{19 I}$ The agency made the policy change in an order. See $i d$. at 509-10.

${ }^{192} I d$. at 515 .

${ }^{193} I d$. at 517 .

${ }^{194} \mathrm{Id}$. at 526-27.

${ }^{195}$ Here, the interests included the potential for substantial monetary fines levied against broadcasters, and a potential chilling effect on protected speech.

${ }^{196}$ See supra text accompanying note 159 (describing basic interests).
} 
that these seatbelts would have a limited impact on safety, since many users would disconnect them. ${ }^{197}$

The Supreme Court, in an opinion written by Justice White, put the agency's arguments through the wringer. What were the agency's reasons for rescinding the rule entirely, instead of adopting an airbagsonly requirement? ${ }^{198}$ Also, studies showed most people used safety belts some of the time. Might this mean that people who disconnected automatic seatbelts would later reconnect them, and then leave them attached? ${ }^{199}$ And why was the agency so quick to reject continuous passive belts? The Court was unconvinced by the agency's arguments that these were unpopular with the public and less safe than other options. $^{200}$

State Farm is famous as the Supreme Court's foray into "hard look" arbitrary and capricious view, in the form pioneered by the D.C. Circuit. ${ }^{20 I}$ But from the minimalist perspective, the State Farm majority's approach looks like overkill, given the nature of the dispute. It is arguably a close question, but I would argue that NHTSA's rule rescission did not pose a serious threat to persons' basic interests. ${ }^{202}$ Nonetheless, the Court insisted on a maximally comprehensive justification for the agency's choice, requiring in effect that the agency demonstrate the superiority of its choices over alternatives. This kind of strict insistence on comprehensive justifications makes sense if the touchstone of administrative legitimacy is the comprehensiveness of its deliberations. But for democratic minimalists, the reason-giving requirement has the more modest goal of ensuring that the agency has not irrationally or maliciously caused serious harm to persons' basic interests. Accordingly, a lesser measure of scrutiny would be appropriate.

\footnotetext{
${ }^{197}$ State Farm Mut. Auto. Ins. Co., 463 U.S. at 38-39.

${ }^{198} \mathrm{Id}$. at 48 .

${ }^{199} \mathrm{Id}$. at $53^{-54}$.

${ }^{200} I d$. at $54^{-56}$.

${ }^{201}$ Sidney A. Shapiro \& Robert L. Glicksman, Congress, the Supreme Court, and the Quiet Revolution in Administrative Law, 1988 DUKE L.J. 819, 863-70 (I988).

${ }^{202}$ NHTSA had previously mandated seatbelts, so the agency's action had not left motorists without life-saving safety features in their cars. See Initial Motor Vehicle Safety Standards, 32 Fed. Reg. 2408, 24I5 (Feb. 3, 1967) (to be codified at 23 C.F.R. pt. 255). As a result, the agency's action here did not leave drivers to face unreasonable risks to life with no means of protecting themselves.
} 
Fudulang concerned a challenge to a policy of the Board of Immigration Appeals (BIA) regarding eligibility to apply for a form of discretionary relief from deportation. Prior to 1996 revisions to the Immigration and Nationality Act (INA), aliens who sought entry to the United States but faced exclusion - generally on the grounds that they had committed criminal offenses specified in the statute, could seek discretionary relief from exclusion. ${ }^{203}$ Executive action and judicial decisions had extended the eligibility to apply for relief to aliens facing deportation, but the BIA had to determine which aliens in deportation proceedings were eligible. Under the "comparable grounds" approach, aliens could apply for relief if the ground for their deportation was comparable to a ground for exclusion listed in the INA. An alien who was denied the opportunity for relief challenged the policy as arbitrary and capricious. In an opinion written by Justice Kagan, the Supreme Court agreed. The Court concluded that the criterion that the agency used to determine eligibility was "irrelevant to the alien's fitness to reside in this country" and was therefore not a reasoned exercise of discretion. ${ }^{204}$

From a democratic minimalism perspective, the fudulang decision gets it right. The context-setting the criteria governing eligibility for relief from deportation - is one in which persons' basic interests are at stake. In such a context, it is appropriate for a court to demand a showing that the agency's decision has adequately taken account of the interests at stake. The Court in fudulang insists it is applying only requiring that the agency's decision be rational, and that it cannot "discern a reason for it". ${ }^{205}$ In fact, the agency gives three reasons for its policy, relating to text, history, and cost; ${ }^{206}$ the Court has really concluded that the agency's reasons are not good enough. And given the stakes for the people affected by the agency's action, the Court is right to insist on a high standard of reasoned decisionmaking here.

That insistence was lacking, at least in part, from the D.C. Circuit's decision in the Hodgson case. The case concerned a challenge to an asbestos standard promulgated by the Occupational Safety and Health Administration (OSHA). Petitioners, the union representing workers exposed to asbestos in their workplaces, challenged a number of aspects of OSHA's "two fiber" standard, including a four-year delay before its

\footnotetext{
${ }^{203}$ Immigration and Nationality Act, 66 Stat. I87, 8 U.S.C. \$ II82(c) (I994).

204 Fudulang, I32 S.Ct. at 484 .

${ }^{205} \mathrm{Id}$. at $485 ; 490$.

${ }^{206} \mathrm{Id}$. at $487^{-9} \mathrm{O}$.
} 
implementation. The petitioners argued that the implementation lag posed a health hazard for workers. The Court had this to say on the subject:

We cannot say, on the basis of the conflicting testimony in the record, that the Secretary erred in his prediction of the health effect of the four year delay, but neither can we say that employees are not exposed to some additional risk of disease because of greater exposure. In view of the Act's express allowance for problems of feasibility, the Secretary's decision to allow a four year delay is not irrational with regard to those industries that require that long to meet the standard. It is appropriate to allow sufficient time to permit an orderly industry-wide transition since, in those cases, the indeterminate degree of risk involved is counterbalanced by considerations of feasibility; it is not, however, a risk to which employees should be needlessly exposed. ${ }^{207}$

This is an issue that implicates workers' basic interests in life and health. Given the stakes, the Court should demand better reasons for delaying the standard than that implementation may involve "problems of feasibility" and that allowing the delay is "not irrational." ${ }^{\circ 8}$ In the Court's defense, it may be that the judges gave scant attention to this particular issue because they found the delay unsupported on other grounds. $^{209}$

\section{What Kinds of Reasons Must Agencies Give?}

We can get a sense for what reasonableness review means by reflecting on an ongoing debate about what kinds of reasons are admissible to justify agency actions.

The reason-giving requirement is foundational to modern administrative law. ${ }^{2 \mathrm{IO}}$ But what kinds of reasons must agencies give for their actions to pass judicial muster? Courts have sometimes set a very high bar indeed for what counts as an adequate justification for an agency action. The Supreme Court's landmark State Farm case, discussed above, illustrates the point. As a practical matter, the majority

\footnotetext{
${ }^{207}$ Indus. Union Dep't, AFL-CIO, 499 F.2d 467, 479 (D.C. Cir. 1974).

${ }^{208} I$ Id.

${ }^{209} I d$. at 480.

${ }^{210}$ See, e.g., Mashaw, supra note 9I.
} 
demanded that the agency demonstrate why its policy was superior to possible alternatives that the agency could have adopted.

Dissenting in State Farm, Justice Rehnquist believed that the reason for the agency's change of course on passive restraints was obvious and adequate:

The agency's changed view of the standard seems to be related to the election of a new President of a different political party. It is readily apparent that the responsible members of one administration may consider public resistance and uncertainties to be more important than do their counterparts in a previous administration. A change in administration brought about by the people casting their votes is a perfectly reasonable basis for an executive agency's reappraisal of the costs and benefits of its programs and regulations. As long as the agency remains within the bounds established by Congress, it is entitled to assess administrative records and evaluate priorities in light of the philosophy of the administration. ${ }^{2 I I}$

Drawing in part on Justice Rehnquist's State Farm dissent, Kathryn Watts has developed the argument that-within carefully specified limits - courts should be receptive to agency justifications of their choices that make reference to political factors. ${ }^{212}$ For instance, where both Options $\mathrm{A}$ and $\mathrm{B}$ are permissible under the statute, the agency should be allowed to explain that it chose Option A because it better aligns with the President's agenda. ${ }^{213}$

Watt's argument has been controversial, with some scholars arguing that letting politics in to judicial review erodes the legitimacy of the administrative process. $^{2 \mathrm{I} 4}$ But from the perspective of democratic minimalism, there is nothing wrong with justifying administrative

${ }^{2 I}$ State Farm Mut. Auto. Ins. Co, 463 U.S. at 59 (Rehnquist, J., dissenting) (footnote omitted).

${ }^{212}$ Kathryn A. Watts, Proposing a Place for Politics in Arbitrary and Capricious Review, II9 YALE L.J. 2 (2009). For the details of her proposal, see id. at 45-73.

${ }^{213} I d$. at $57^{-62}$.

${ }^{214}$ See, e.g., Jodi L. Short, The Political Turn in American Administrative Law: Power, Rationality, and Reasons, 6I DUKE L.J. I8II (20I2); Enrique Armijo, Politics, Rulemaking, and Judicial Review: A Response to Professor Watts, 62 ADMIN. L. REV. 573 (2010). 
decisions with reference to legitimate political considerations. ${ }^{215}$ Minimalism offers a less demanding conception of democracy than most of its competitors, and a less demanding set of legitimacy conditions translates into a larger set of reasons for agency action that count as legitimate. Within this perspective, a political explanation for an otherwise reasonable policy choice is good enough. If political influences on agencies' decisions are not democratically disqualifying, and to a minimalist they are not, then there is no reason to prohibit agencies from acknowledging them. Among other benefits, permitting agencies to acknowledge political influences could help put an end to the tiresome charade in which agencies pretend that the reasons they state publicly are the reasons for their actions, and the courts pretend to believe them.

\section{Chevron Revisited}

This simple framework for judicial review can be integrated with doctrinal structures designed for particular contexts within administrative law, such as the judicial review of agency statutory interpretations. In administrative law, debate over how courts should review agency interpretations of statutes revolves around discussions of Chevron deference: what exactly it entails, and when it should apply. This section brings the minimalist framework to bear on how and when Chevron should operate.

Famously, the I984 case Chevron USA, Inc. v. Natural Resources Defense Council, Inc., ${ }^{216}$ defines a two-step inquiry for reviewing courts when evaluating agency constructions of statutes that they administer. First, the court asks whether Congress has spoken directly to the precise question at issue in the statute. If the answer is yes, then Congress's intent, as expressed in the statute, controls. If the answer is no- that is, if the statute is ambiguous with respect to the question- then the court is to uphold the agency's construction so long as it is reasonable.

Chevron, like minimalism itself, is a doctrine of "good enough." An agency's interpretation of a statute doesn't have to be the best interpretation from the reviewing court's perspective: it will be upheld so long as it is reasonable. Chevron also shares with democratic

${ }^{215}$ As Watts discusses, some political reasons - for instance, naked preferences for one group over another-would certainly not be adequate justifications for agency choices. Watts, supra note $2 \mathrm{I} 2$, at 52 .

${ }^{218}$ Chevron, U.S.A., Inc., 467 U.S. 837 (1984). 
minimalism a certain political realism, at least when compared with its competitors. Cheoron receives the attention it does in part because of its unprecedented, candid acknowledgment that questions of statutory interpretation, far from being merely matter of legal technique, really are stalking horses for political choices. If the gaps in statutes really are opportunities to make policy choices, Cheoron argued, they are better made by executive branch officials than courts.

One of the questions arising under Chevron concerns the nature of the review courts are to conduct at Step Two. A number of scholars have argued that Step Two review amounts to, or should amount to, the same thing as the arbitrary and capricious review that courts apply to exercises of agency discretion, ${ }^{217}$ and the Supreme Court has suggested that it agrees. ${ }^{28}$ From a minimalist perspective, I would agree that these standards should be the same, and more specifically, that they should be the standard described above: a baseline reasonableness review, with elevated scrutiny when it appears the agency's inadequate attention to relevant basic interests caused serious harms. This has the nice feature of harmonizing well with the language of Cherron, which instructs courts to allow reasonable constructions of ambiguous statutes.

From a minimalist perspective, Cherron is a sensible doctrine. Step One is a threshold inquiry establishing that the agency in fact has some discretion within the statute at issue, and then Step Two assures that the agency uses its discretion in a reasonable way. As a whole, Cherron leaves agencies ample room to choose a course of action while working as a check against domination.

In recent years, however, the fate of Chevron has become unclear. A number of decisions have established carve-outs from Chevron review, prescribing higher scrutiny instead, ${ }^{219}$ although some cases have pushed in the other direction. ${ }^{220}$ To take a very high-profile recent example, in King v. Burwell, Chief Justice Roberts rejected out of hand the suggestion that Chevron deference was owed to the Treasury Department's interpretation of the Patient Protection and Affordable

${ }^{217}$ See, e.g., I RICHARD J. PIERCE, JR., ADMINISTRATIVE LAW TREATISE $\$ 7.4$, at 453 (2OO2); Ronald M. Levin, The Anatomy of Chevron: Step Two Reconsidered, 72 CHI.-KENT L. REV. I253, I280-86 (I997).

${ }_{218}^{218}$ fudulang, 132 U.S. 476 (2OII).

${ }_{219}^{219}$ See, e.g., United States v. Mead, 533 U.S. 218 (200I).

${ }^{220}$ See, e.g., Nat'l Cable \& Telecom. Ass'n v. Brand X Internet Servs., 545 U.S. $967(2005)$. 
Care Act. ${ }^{221}$ On occasion, the Court has nominally applied Chevron, but in anything but a spirit of deference. ${ }^{222}$ Moreover, empirical work indicates that the Supreme Court routinely declines to apply Chevron without comment in circumstances that, according to the Court's own doctrine, Chevron should apply. ${ }^{223}$ In lieu of Chevron, courts typically review agencies' interpretations of statutes within less deferential frameworks, such as the sliding-scale Skidmore deference.

From the perspective of democratic minimalism, these incursions into Chevron's domain ${ }^{224}$ are suspect. Chevron provides enough scrutiny to block agency actions that amount to domination, but not so much as to derail or ossify legitimate agency decision-making processes. There may be reasons to provide less deference in some circumstances, but courts should articulate clearly why and when additional scrutiny is warranted.

\section{E. Rethinking Reviewability}

This last point relates not to bow judicial review should be conducted, but when.

A raft of administrative law doctrines erect potential barriers to obtaining judicial review. These include ripeness, mootness, standing, finality, and (in some cases) exhaustion and primary jurisdiction. Moreover, contemporary administrative law gives radically divergent treatment to agency action and agency failures to act - notwithstanding the fact that the APA defines agency action to include the failure to act. ${ }^{225}$ To a democratic minimalist, these doctrines deserve some scrutiny, to ensure they are not applied in ways that unfairly harm parties in their basic interests.

Reviewability doctrines serve the important purpose of keeping out of the courts matters that should be handled by agencies in the first instance. ${ }^{226}$ And in some instances, courts have pursued this purpose in

${ }^{221} \mathrm{King}$, et al. v. Burwell, 576 U.S. _ (2015).

${ }^{222}$ See, e.g., General Dynamics Land Systems, Inc. v. Cline 540 U.S. 58I (2004).

${ }^{223}$ William N. Eskridge \& Connor Raso, Chevron as a Canon, not a Precedent: An Empirical Test of what Motivates Fudges in Agency Deference Cases, II COLUM. L. REV. 1727 (2OIO).

${ }^{224}$ The first article to discuss the concept of Cherron's domain is Thomas W. Merrill \& Kristin E. Hickman, Chevron's Domain, 89 GEO. L.J. 833 (200I).

${ }_{222}^{225}$ U.S.C. $\$ 55 \mathrm{I}(\mathrm{I} 3)(2 \mathrm{OI} 2)$.

${ }^{226}$ Over time, standing doctrine has acquired a constitutional dimension that now overshadows these prudential concerns. See Lujan v. Defenders of Wildlife, 504 U.S. 555 (I992). 
a manner appropriately sensitive to potential litigants' interest in access to courts. Ripeness doctrine is a good example. In Abbott Laboratories $v$. Gardner, the Supreme Court was asked to determine whether a preenforcement challenge to a regulation was ripe for judicial review. The question of ripeness, the Court held, "require[es] us to evaluate both the fitness of the issues for judicial decision and the hardship to the parties of withholding court consideration."227 The doctrine works out to require pre-enforcement review when delaying judicial review would impose a substantial harm on the plaintiff.

The facts of Abbott Laboratories illustrate how denying pre-enforcement review can amount to domination of the regulated party. Abbott, a pharmaceutical company, argued that an FDA regulation governing the labeling of prescription drugs was invalid. In the absence of preenforcement review, if Abbott wished to challenge the validity of the regulation, it would need to defy it, and wait for an enforcement action from the FDA. As a defense, Abbott could collaterally challenge the validity of the regulation. But even if Abbott took this course and ultimately prevailed at trial, for a drug maker to openly defy FDA regulations would have ruinous consequences for its reputation. ${ }^{228}$ In effect, then, Abbott had one realistic option: to comply with a regulation that was (by hypothesis) invalid. So as a practical matter, a denial of preenforcement review would complete vitiate Abbott's right to lawful agency action. Appropriately, the Supreme Court held that Abbott's challenge was ripe, and pre-enforcement review remains the standard practice.

Other limits on reviewability have developed in ways that work substantial unfairness on would-be litigants, however. The way courts handle challenges to agency inaction is the chief offender. As noted above, the APA provides for review of agency action, and declares that agency action includes "failure to act."229 But in his opinion for the Court in Norton v. Southern Utab Wilderness Alliance, ${ }^{230}$ Justice Scalia

${ }_{227}^{228}$ Abbott Laboratories et al., v. Gardner, 387 U.S. I36, I49 (1967).

${ }^{228} \mathrm{Id}$. at ${ }_{153}$ " $I t$ is relevant at this juncture to recognize that petitioners deal in a sensitive industry, in which public confidence in their drug products is especially important. To require them to challenge these regulations only as a defense to an action brought by the Government might harm them severely and unnecessarily."

${ }_{229} 5$ U.S.C. $\$ 55 \mathrm{I}(\mathrm{I} 3)(20 \mathrm{I} 2)$.

${ }^{230}$ Norton et al., v. Southern Utah Wilderness Alliance et al., 542 U.S. 55 (2004). 
defined very narrowly the kinds of agency inaction that are subject to review. A textual analysis of the definition of agency action led Justice Scalia to the conclusion that "a claim under $\$$ 706(I) can proceed only where a plaintiff asserts that an agency failed to take a discrete agency action that is it required to take. ${ }^{231}$ Precisely because agencies are granted significant discretion even with respect to tasks they must undertake, requiring litigants to point to a specific thing that agencies bave to do comes close to rendering the right to review failures to act a dead letter.

To a minimalist, this is a problem because agency inaction can pose threats to persons' basic interests just as much as agency actions can. A case from the Third Circuit illustrates the point. Hexavalent chromium, a chemical compound with certain industrial applications, is a human carcinogen, and a potent one. According to a study conducted by OSHA, workers exposed to IOo micrograms per cubic meter of hexavalent chromium on a daily basis over a working lifetime could anticipate excess cancer deaths in the eye-popping range of 88 to 342 per Iooo. $^{232}$ And yet, OSHA set the permissible exposure limit (PEL) to Ioo micrograms per cubic meter, and failed to lower the limit for over thirty years, even once it became clear that the existing standard was grossly inadequate to protect human health, and in the face of a lawsuit seeking to force the agency to act. ${ }^{233}$

Here is a situation where workers' most basic interest-in life-is threatened by the agency's failure to take action in accordance with its mandate to protect workers against toxic materials. ${ }^{234}$ Minimalism highlights how an unnecessarily crabbed reading of the APA's definition of "agency action" makes our system of government less democratic, if it arbitrarily subjects persons to substantial harms without possibility of remedy. A different reading of the statute could establish at least a rough symmetry between the kind of justification an agency has to provide

\footnotetext{
${ }^{231} \mathrm{Id}$. at 64 .

${ }^{232}$ Public Citizen Health Research Group v. Chao, 314 F.3d I43, I47 (2002).

${ }^{233}$ By way of comparison, the PEL for asbestos is expected to result in 6.7 additional cancer deaths per IO०O workers. Occupational Exposure to Asbestos, 59 Fed. Reg. 40,964, 40,978 (Aug. IO, 1994).

${ }^{234}$ See Occupational Safety and Health Act of 1970,29 U.S.C. 655, \$ 6(b)(5) ("The Secretary in promulgating standards dealing with toxic materials or harmful physical agents under this subsection shall set the standard which most adequately assures, to the extent feasible, on the basis of the best available evidence, that no employee will suffer material impairment of health or functional capacity even if such employee has regular exposure to the hazard dealt with by such standard for the period of his working life.").
} 
whether its action or inaction results in serious harm. When parties can show that they are harmed in their basic interests by agencies' failures to take actions properly within their power, courts could require agencies to explain why, notwithstanding their careful attention to the affected interests, other considerations persuasively counseled against taking the action requested.

Other reviewability doctrines also elevate formalism over the protection of those vulnerable to exercises of administrative power. Finality doctrine, for instance, means that an important class of agency decisions evade judicial review entirely, even though they may have substantial impacts. Dalton v. Specter ${ }^{235}$ and Bennett v. Spear ${ }^{236}$ establish that when the formal responsibility for ratifying an agency's decision rests with the President, review is not available: the agency's work cannot be reviewed because it is not final without action by the President, and the President's action cannot be reviewed because the President is not an agency. Recent circuit court decisions have held that guidance documents advising parties on agency statutory interpretations ${ }^{237}$ and U.S. Army Corps of Engineers determinations that private property is wetland, and hence protected under the Clean Water Act, ${ }^{238}$ are not final, and therefore not reviewable. As a practical matter, such rulings irrevocably foreclose development on the affected lands. Decisions such as these effectively strip parties of their legal protection against arbitrary agency actions that potentially have serious consequences, and therefore are suspect.

In the case of OSHA and hexavalent chromium, the Third Circuit ultimately did order the agency to promulgate a new standard. ${ }^{239}$ In part, the agency had hoist itself on its own petard, by repeatedly acknowledging the need to take action and promising to do so, before lapsing again and again into lassitude. And the Third Circuit's ruling only came after more than thirty years of delay on the agency's part. From the standpoint of democratic minimalism, it should not be so

\footnotetext{
${ }^{235}$ Dalton et al. v. Specter et al., 5II U.S. 462 (1992).

${ }^{236}$ Bennett et al. v. Spear et al., 520 U.S. I54 (1997).

${ }^{237}$ Ass'n of Flight Attendants-CWA, AFL-CIO v. Huerta, 785 F.3d 7 Io (D.C. Cir. 2015).

${ }^{238}$ Belle Co., LLC v. U.S. Army Corps of Engineers, 761 F.3d 383 (2014), cert. denied, 135 S. Ct. 1548 (2015).

${ }^{239} \mathrm{Id}$. The regulation finally took effect in 2006. 7I Fed. Reg. IO,IOO (Feb. 28 2006) (to be codified at 29 C.F.R. ch. XVII).
} 
difficult to have courts force agencies to do their job when lives are at stake. $^{240}$

\section{CONCLUSION}

The previous Part laid out a model of judicial review in administrative law aimed at reducing domination. The basic prescription is for a baseline of reasonableness review, with elevated scrutiny under circumstances where agency failures appear to have caused parties significant harm to their basic interests. I played out the implications of this way of looking at judicial review for Cheoron review, for the kinds of reasons agencies should have to give, and for the availability of review.

Some might object that these prescriptions for judicial review ask courts to do work for which they are not cut out. Specifically, tying the intensity of review to the impact agency action has on parties requires judgments from courts that are both fact-intensive and value-based. What impacts an agency action has on people is an empirical question, and not always an easy one to answer. And judgments about what kinds of harms count as serious necessarily involve contestable assumptions about what interests are really important.

Relatedly, one might conclude that this framework for review is especially ill-suited to complex, technical regulatory environmentswhich are so many of the environments in which agencies are active. The human dimension can be hard to see when it comes to, for instance, the regulation of power grids. What guidance, if any, can minimally democratic administrative law provide to courts working in this or similar areas?

These objections have some force: this minimally democratic conception would change aspects of judicial review, and not necessarily in ways that play to courts' strengths. I do not dismiss them, and to the extent they are convincing, they are reasons against reworking judicial review along the lines described above. But I do argue that these objections are not as compelling as they might appear at first glance.

First, while the minimalist framework would require courts to make assessments of the potential harm that agency actions pose, it is

240 For this reason, the elimination of exhaustion as a freestanding reviewability requirement is a salutary development from the perspective of democratic minimalism. See Darby v. Cisneros, 509 U.S. 137 (I993). 
important to be clear about when and why this might be difficult for judges. Assessing harms in general is by no means outside of judges' skill set. Courts must judge harm to parties, for instance, in determining whether to grant a preliminary injunction. ${ }^{241}$ Judges sometimes determine both compensatory and punitive damages. ${ }^{242}$ The Matheres $v$. Eldridge due process framework requires courts to assess the adverse impact that agency procedures have on claimants who appear before the agency. ${ }^{243}$ While the analysis prescribed above for determining whether heightened scrutiny is warranted is not identical to any of these, it is not necessarily any more difficult or more unpredictable, at least much of the time. ${ }^{244}$

Complex and technical regulatory environments pose difficulties for judicial review in general: courts reviewing agency choices in areas requiring subject-specific expertise can quickly find themselves out of their depth. What is most distinctive about the minimalist framework is that it requires courts to assess whether the agency action threatens serious harm to persons. Complex and technical areas are likely to pose greater challenges for the minimalist framework of review review, relative to other forms of judicial review, only insofar as this inquiry into the potential for harm is a difficult one in these areas. But frequently, these assessments will not require technical knowledge, even in technical areas. For instance: the regulation of nuclear power plant safety is an immensely technical field. But the potential impact of a regulatory failure on people's basic interests is readily apparent. If a party makes a credible claim that a decision by the Nuclear Regulatory Commission to waive fire safety requirements for certain reactors gave insufficient consideration to the interests of persons living near them,

${ }^{241}$ See, e.g., Monsanto Co. v. Geertson Seed Farms, 56I U.S. 139, I4I (describing the preliminary injunction standard).

${ }^{242}$ In a sample of 2005 state cases collected by Theodore Eisenberg and Michael Heise, more than $30 \%$ of cases in which punitive damages were requested were tried by judges. Theodore Eisenberg and Michael Heise, FudgeFury Difference in Punitive Damages Awards: Who Listens to the Supreme Court?, J. EMPIRICAL LEG. STUD. 325, 33I (20II).

${ }^{243}$ See Mathews v. Eldridge, 424 U.S. 319 (1976).

${ }^{244}$ See supra text accompanying notes 176 to 178 , and Jud Mathews, Deference Lotteries, 9I TEX. L. REV. 1349 (2013), on the unpredictability of judicial review. 
then a reviewing court should demand a clear showing from the agency to the contrary. ${ }^{245}$

The need to reconcile the fact of administrative power with our democratic commitments animates so much of administrative law, but just what does a commitment to democratic governance entail? A minimalist might argue that the core idea of democracy is not representation, or deliberation, or even electoral accountability, but the principle of non-domination. This Article has reevaluated a cornerstone of administrative law, the review of agency action by courts, from the standpoint of democratic minimalism. I have argued from minimalist premises in favor of a variable intensity of review framework that combines a default norm of reasonableness review with the possibility for more intensive scrutiny when the risk of domination is higher. I have also weighed in, from this perspective, on debates over the scope of Cheoron review, the admissibility of political reasons to justify agency action, and the availability of judicial review.

This project is, in important respects a modular one: the argument has different stages, and one could accept some while rejecting others. One could agree that the conceptions of democracy reflected in contemporary administrative thinking are problematic and disagree that a minimalist approach is preferable. Or one could endorse a minimalist conception of democracy but reject one oriented around the concept of non-domination. One could even accept this particular minimalist conception of democracy and disagree about what it implies for judicial review. Indeed, the framework for judicial review outlined above is intended to be more illustrative than definitive. The ultimate ambition of this Article is not to offer a comprehensive prescription for administrative reform so much as it is to stimulate further attention to the important question of what our democratic commitments mean for our administrative practices.

${ }^{245}$ See Brodsky v. U.S. Nuclear Regulatory Comm'n, 783 F.Supp.2d 448 (S.D.N.Y. 20II) (holding that the agency had adequately taken safety considerations into account in granting the waiver). 